\title{
CONTRIBUTION TO THE STIGMAEIDAE (ACARI: PROSTIGMATA) FAUNA OF THE ALTAI REPUBLIC, RUSSIA
}

\author{
Alexander A. Khaustov
}

Tyumen State University, Tyumen, Russia

e-mail: alex1973khaustov@gmail.com

ABSTRACT: During a study of predatory mites of Western Siberia, 13 species of the family Stigmaeidae (Acari: Prostigmata) have been recorded from the Altai Republic, Russia. Stigmaeus akimovi sp.n. and Eustigmaeus summersi sp.n. are described as new to science. Mediolata uspenskii and Eustigmaeus acidophilus have been recorded from Russia for the first time and redescribed based on materials from Altai. Stigmaeus purpurascens, S. Iongipilis, S. sphagneti, S. delaramae, Mediolata pini, Eustigmaeus segnis, E. rhodomelus, E. parvisetus and Cheylostigmaeus sp. have been recorded from the Altai Republic for the first time.

KEY WORDS: Acarina, Raphignathoidea, systematics, morphology, Russia.

DOI: 10.21684/0132-8077-2021-29-1-43-66

\section{INTRODUCTION}

The mite family Stigmaeidae (Acari: Prostigmata) is the largest in the superfamily Raphignathoidea and currently includes about 635 species of 33 valid genera (Fan et al. 2016, 2019; Beron 2020; Khaustov 2021). Most stigmaeid mites are freeliving predators of various small arthropods. Some Eustigmaeus species feed on mosses, while several Stigmaeus and Eustigmaeus species are parasites of sand flies (Diptera: Psychodidae). Species of the genera Zetzelia and Agistemus are probably the second most important group of plant mite predators (after the Phytoseiidae) (Gerson et al. 2003).

The stigmaeids of Western Siberia have been studied mostly in Tyumen and Kurgan Regions (Khaustov and Tolstikov 2014; Khaustov 2014, 2015, 2016, 2020, 2021; Khaustov and Abramov 2017), while other regions remain poorly studied. The Stigmaeidae fauna of the Altai Republic is completely overlooked.

During a study of stigmaeid mites of the Altai Republic, Russia, we have recorded 13 species. Stigmaeus akimovi sp.n. and Eustigmaeus summersi sp.n. are described as new to science; $M e-$ diolata uspenskii and Eustigmaeus acidophilus have been recorded from Russia for the first time and redescribed based on materials from Altai. This article also provides data on the distribution of other species.

\section{MATERIALS AND METHODS}

Samples of soil, forest litter and mosses were collected in the Altai Mountains (Altai Republic, Russia) on different altitudes (400-3,000 m a.s.1.). Mites were collected from samples using Berlese funnels and mounted in Hoyer's medium. In the description below, the palpal, idiosomal and leg seta- tions follow Grandjean $(1939,1944,1946)$. The nomenclature of prodorsal setae follows Kethley (1990). The nomenclature of the idiosomal shields follows that of Summers (1962). All measurements for the holotype and for the paratypes (in parentheses) are given in micrometres $(\mu \mathrm{m})$. In the descriptions of leg setation, the number of solenidia is given in parentheses. All materials are deposited in the mite collection of the Tyumen State University Museum of Zoology, Tyumen, Russia. Mite morphology was studied using a Carl Zeiss AxioImager A2 compound microscope with a phase contrast and DIC objectives.

\section{SYSTEMATICS}

\section{Family Stigmaeidae Oudemans, 1931 Genus Stigmaeus Koch, 1836}

Type species: Stigmaeus cruentus Koch, 1836, by subsequent designation by Berlese (1910).

\section{Stigmaeus akimovi sp.n.}

(Figs. 1-6)

Description. Female (Figs. 1-4). Idiosoma ovate. Length of idiosoma 430 (430-450), maximum width 265 (260-300).

Idiosomal dorsum (Fig. 1A). Central shield with two pairs of setae $c l$ and $d l$; median zonal and intercalary shields paired. All shields with poorly sclerotized subcuticular reticulation with poorly visible dorsal dimples. Postocular bodies round, without reticulate microsculpture; diameter of postocular bodies shorter than distance between their median margins. Eyes absent. Striation anterolaterad prodorsal plate with microtubercles. Setae ve and $c 2$ pointed, smooth or with few very small barbs; other dorsal setae weakly blunt-tipped and 

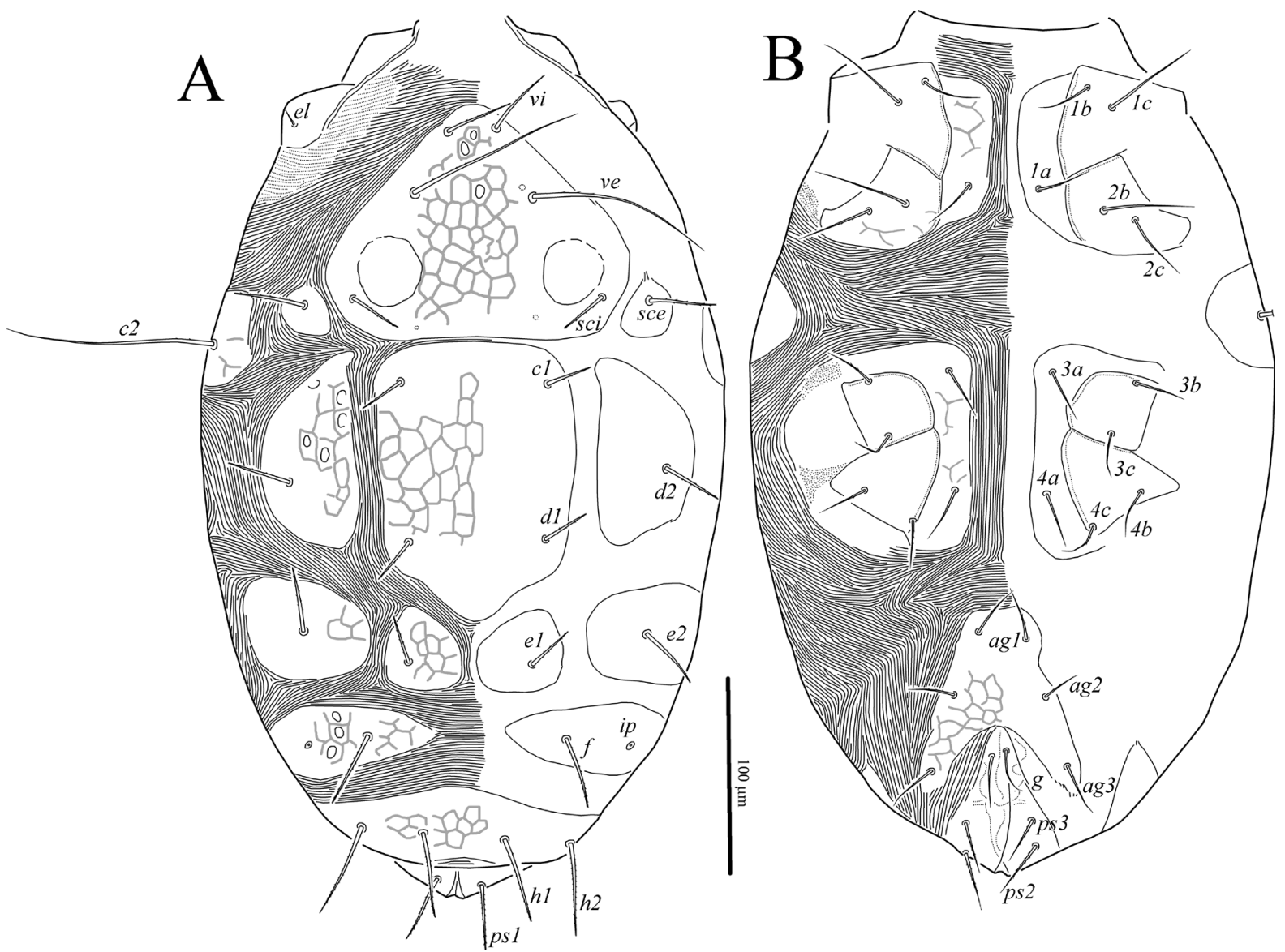

Fig. 1. Stigmaeus akimovi sp.n., female: A—dorsum of idiosoma, B—venter of idiosoma.

with small barbs. Lateral parts of intercalary shields with poorly visible cupules ip. Setae $p s 1$ located dorsally. Length of dorsal setae: vi 36 (36-40), ve 91 (78-91), sci 28 (28-29), sce 35 (33-36), c1 24 (23-25), c2 105 (100-105), d1 26 (23-28), d2 31 (29-34), e1 26 (24-28), e2 34 (32-35), f38 (38-40), $h 144$ (42-44), h2 47 (47-54).

Idiosomal venter (Fig. 1B). Aggenital and endopodal plates with weak subcuticular reticulation. All ventral setae pointed, smooth or weakly barbed. Aggenital plate with three pairs of aggenital setae; one pair of genital setae. Length of ventral setae: $1 a 26$ (26-29), $1 b 28$ (27-29), 1c 54 (47-54), $2 b$ 51 (47-51), 2c 35 (35-38), 3a 27 (27-33), 3b 29 (26-29), 3c 24 (24-28), 4a 30 (30--33), 4b 25 (25-26), 4c 25 (25-26), agl 28 (27-29), ag2 22 (26-27), ag3 30 (28-30), g 25 (21-25), ps1 38 (36-38), ps2 30 (30-32), ps3 25 (25-29).

Gnathosoma (Fig. 2). Tibial claw large, about as long as palptarsus. Setae $l$ ' on palpal tibia short spiniform. Seta $d$ of palpfemur weakly blunt-tipped, other setae of femur, genu and tibia pointed. All setae of femur, genu and tibia and seta $v a$ of tarsus weakly barbed; other setae of palptarsus smooth.
Number of setae on palpal segments: $\operatorname{Tr} 0, \mathrm{Fe} 3(d$, $l$ ', v'), Ge 2 (d, l'), Ti 3 (d, l', l'), Ta 8(1) (fused eupathidia $u l$ ', $u l$ ", sul, eupathidion $a c m, b a, b p$, $l p, 1$ solenidion $\omega)$. Palpal supracoxal setae $(e p)$ thin, almost setiform, with slightly rounded tip. Rostrum of subcapitulum relatively long. All subcapitular setae pointed; orl smooth, other subcapitular setae weakly barbed. Basal part of subcapitulum without distinct reticulation, smooth. Length of subcapitular setae: $m 30$ (28-30), $n 29$ (28-32), or1 21 (21-25), or2 25 (25-28). Length of palps $110(110-120)$; length of cheliceral stylets 60 (59-61), length of tarsal solenidion 8 (7-8).

Legs (Figs. 3, 4). Length of legs: I 215 (215240), II 170 (170-190), III 165 (170-190), IV 200 (195-210). Leg segments without distinct reticulation. Empodial raylets with slightly widened tips. Leg I (Fig. 3A). Coxae I posterodorsally with short setiform leg supracoxal setae $(e l)$. Leg setation: $\mathrm{Tr}$ 1 ( v'), Fe 6 (d, l', l', v', v', bv'), Ge 4 (d, l', l', $k$ ), $\operatorname{Ti}$ 5(2) (d, l', l', v', v'”, $\varphi, \varphi p)$, Ta 13(1) ( $p^{\prime}, p^{\prime \prime}, t c^{\prime}$, tc", ft', ft", u', u', a', a', $p l$ ', $p l$ ', $v s, \omega)$. Setae $k$ of genu, $d$ of tibia and $(p),(t c),(f t)$ of tarsus smooth, blunt-tipped, eupathid-like; other setae sparsely 

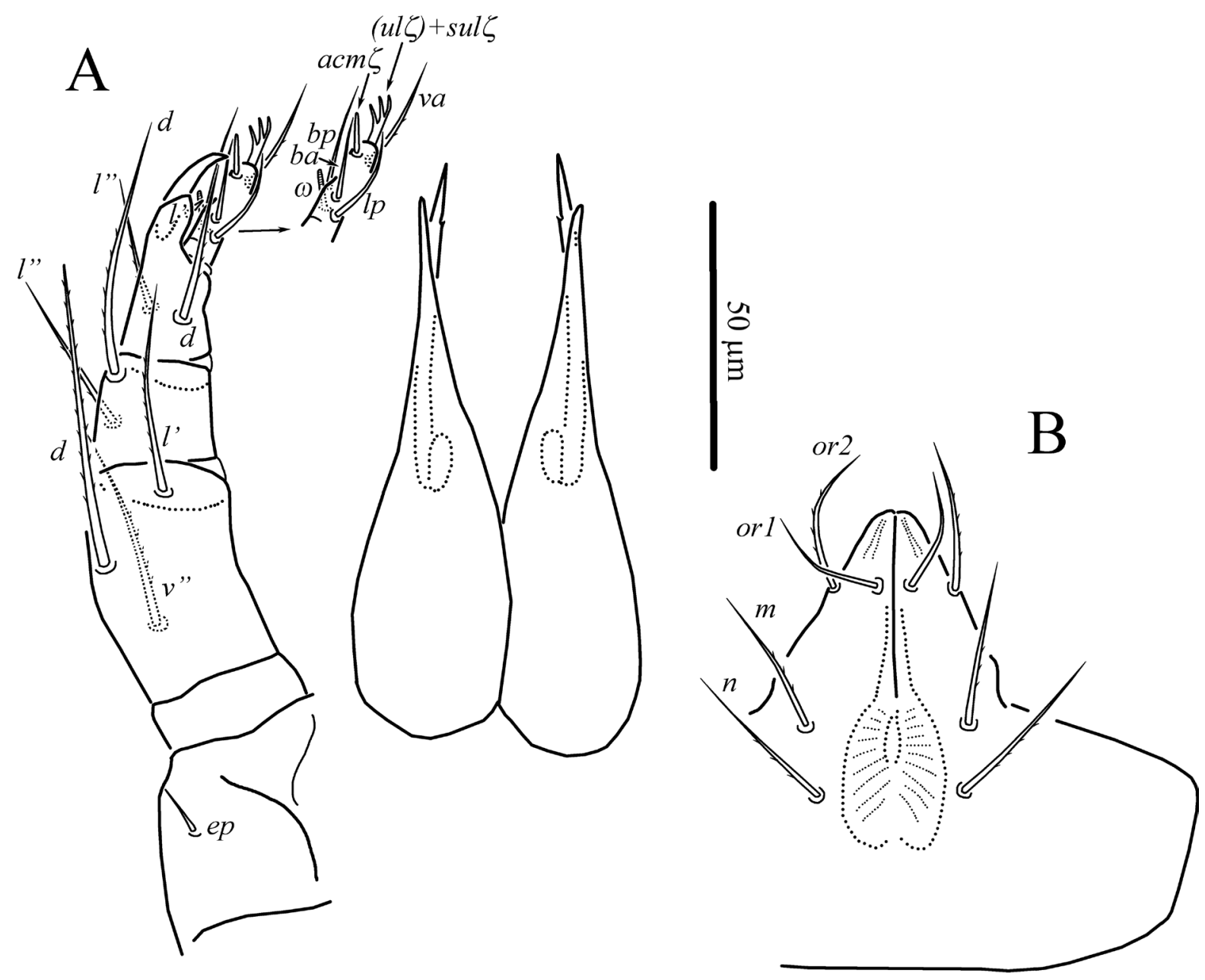

Fig. 2. Stigmaeus akimovi sp.n., female: A—gnathosoma, dorsal aspect; B—subcapitulum.

barbed; setae $d, l$, $v$ " of femur and $d$ of genu weakly blunt-tipped, other setae pointed. Seta $d$ of genu distinctly longer than seta $k 19$ (19-20). Solenidion $\omega 15$ (15-16) finger-shaped; solenidion $\varphi$ 11 (10-11) baculiform, $\varphi p 37$ (36-41) attenuate, with rounded tip. Leg II (Fig. 3B). Leg setation: Tr $1\left(v^{\prime}\right), \mathrm{Fe} 5$ (d, l', l', v', $\left.b v^{\prime \prime}\right), \mathrm{Ge} 4\left(d, l, l^{\prime \prime}, k\right)$, Ti 5(1) $\left(d, l^{\prime}, l^{\prime \prime}, v^{\prime}, v^{\prime \prime}, \varphi p\right)$, Ta 9(1) ( $p^{\prime}, t c^{\prime}, t c^{\prime \prime}, u^{\prime}$, $u^{\prime \prime}, a^{\prime}, a^{\prime \prime}, p l$ ', $\left.v s, \omega\right)$. Setae $k$ of genu, $d$ of tibia, $p^{\prime}$ and $t c$ ' of tarsus smooth, blunt-tipped, eupathid-like, other setae weakly barbed; seta $d$ of femur weakly blunt-tipped, other setae pointed. Solenidion $\omega 15$ (14-15) finger-shaped; solenidion $\varphi p 33$ (28-35) attenuate, with rounded tip. Seta $k$ short 5 (5-7), more than two times shorter than setae $d$ of genu. Leg III (Fig. 4A). Leg setation: $\operatorname{Tr} 2\left(v^{\prime}, l^{\prime}\right), \mathrm{Fe} 3(d$, $\left.l^{\prime}, e v^{\prime}\right)$, Ge $1(d)$, Ti 5(1) (d, l', l’, v', v', $\left.\varphi p\right)$, Ta 7(1) (tc', tc", $\left.u^{\prime}, u^{\prime \prime}, a^{\prime}, a^{\prime \prime}, v s, \omega\right)$. Solenidion $\omega$ 10 (10-11) finger-shaped; solenidion $\varphi p 29$ (28-30) attenuate, with rounded tip. All setae weakly barbed; seta $d$ of femur weakly blunt-tipped, other setae pointed. Leg IV (Fig. 4B). Leg setation: $\operatorname{Tr} 1\left(v^{\prime}\right)$, Fe $2\left(d, e v^{\prime}\right), \operatorname{Ge} 1(d)$, Ti 5(1) (d, l', l’, $\left.v^{\prime}, v^{\prime \prime}, \varphi p\right)$, Ta 7(1) (tc', tc', $\left.u^{\prime}, u^{\prime \prime}, a^{\prime}, a^{\prime \prime}, v s, \omega\right)$. Solenidion $\omega 11$ (10-11) finger-shaped; solenidion $\varphi p 31$ (28-31) attenuate, with rounded tip. All setae weakly barbed; setae $d$ of femur and genu weakly blunt-tipped, other setae pointed.

Male (Figs. 5, 6). Length of idiosoma 300-310, width 200-205.

Idiosomal dorsum (Fig. 5A). Prodorsum as in female. Marginal shields fused with central shield; median zonal and intercalary shields fused together. All dorsal shields with poorly visible dimples and subcuticular reticulation, Setae $p s 1-3$ located dorsally; setae $p s 1-2$ very small, spiniform, setae $p s 3$ pointed and weakly barbed, other dorsal setae as in female. Aedeagus poorly sclerotized, hardly visible. Length of dorsal setae: vi 29, ve 45-55, sci 19, sce 26, c1 17-18, c2 52-61, d1 17-18, d2 21-24, e1 17, e2 23-24, f 26-27, hl 17-18, h2 34-35, ps1 2, ps2 2, ps3 15-18. 


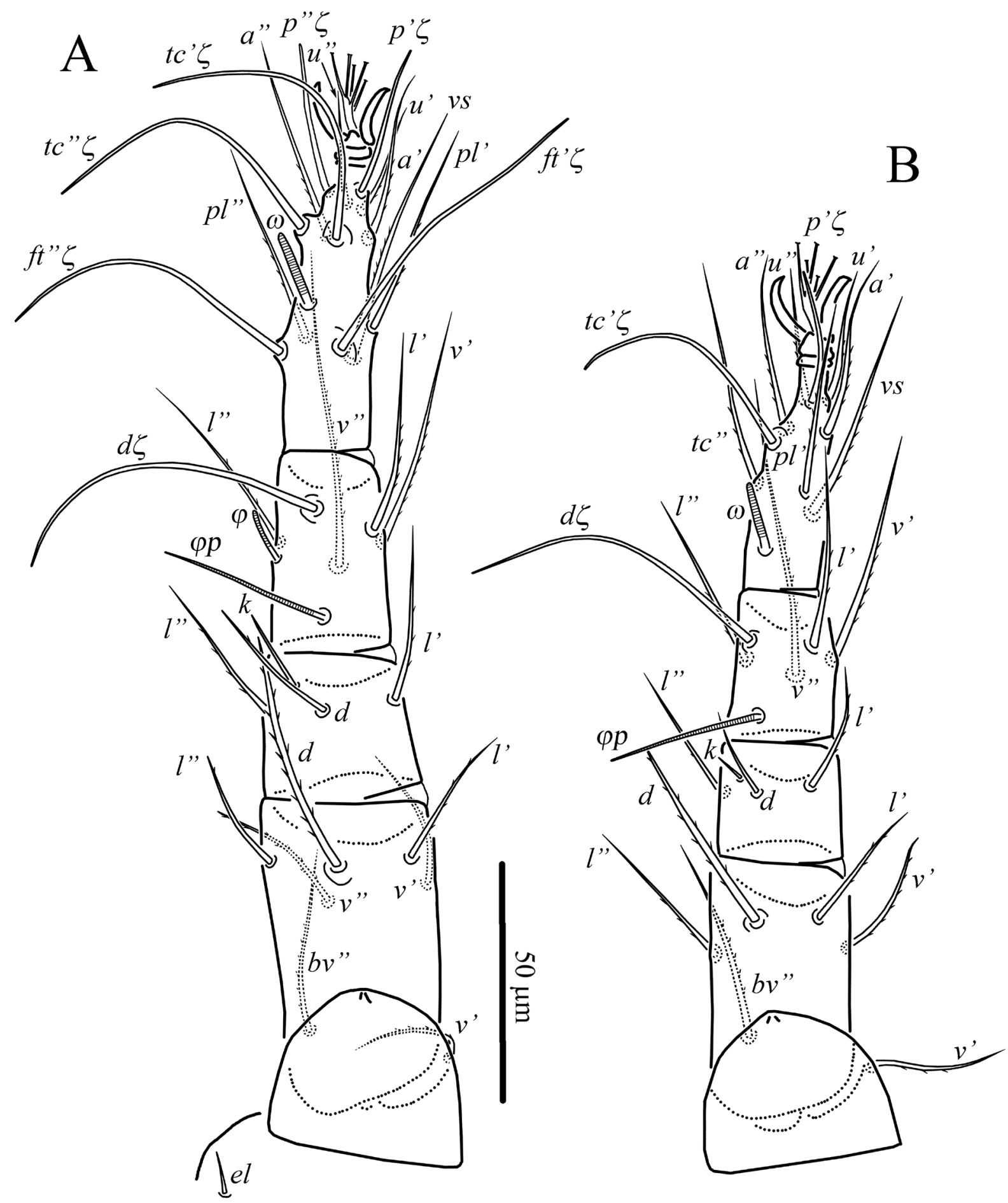

Fig. 3. Stigmaeus akimovi sp.n., female: A-left leg I, dorsal aspect; B-left leg II, dorsal aspect.

Idiosomal venter (Fig. 5B). Opisthosomal venter with three pairs of weakly barbed and pointed aggenital setae located on large, weakly reticulated aggenital plate; podosomal venter as in female. Lengths of ventral setae: $1 a$ 28-30, $1 b$ 22-25, 1c 30-34, 2b 29-33, 2c 19-24, 3a 22-25, $3 b 22-23,3 c$ 20-23, 4a 23-25, 4b 21-24, 4c 20-23, ag1 22-23, ag2 21-22, ag3 23-25.
Gnathosoma as in female. Length of subcapitular setae: $m$ 22-25, $n$ 23-24, or 1 17-19, or 2 22-23; ; length of palps 88-94; length of palpal solenidion $\omega 6-7$; length of cheliceral stylets 49-50.

Legs (Fig. 6). Legs as in female, except presence of well-developed male solenidia on tarsi I-IV. Lengths of solenidia and setae $k: \omega \mathrm{I} 14-17, \omega{ }^{\lambda} \mathrm{I}$ 23-24, $\varphi$ I 8-10, $\varphi$ I 24-29, kI 15-16, $\omega$ II 11-14, 

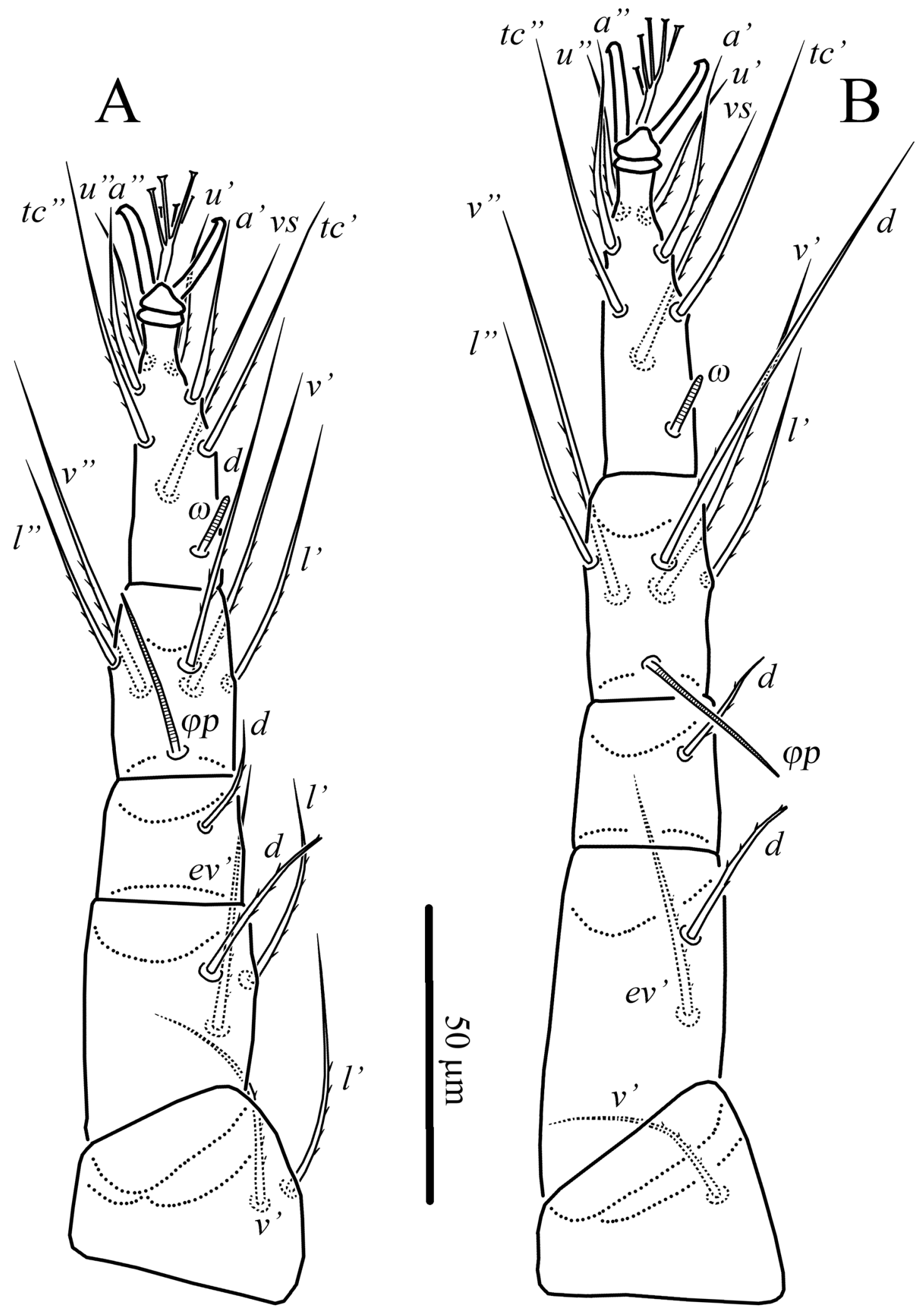

Fig. 4. Stigmaeus akimovi sp.n., female: A—left leg III, dorsal aspect; B—left leg IV, dorsal aspect.

$\omega{ }^{\lambda} \mathrm{II} 22-24, \varphi p$ II 23-26, $k \mathrm{II} 8, \omega \mathrm{III} 10, \omega{ }^{\lambda} \mathrm{III} 22-$

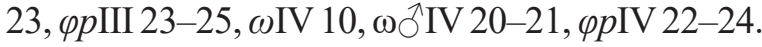
Immatures unknown.
Type material. Female holotype, slide № AK310720, Ulagansk District, 50 $18^{\prime} 56^{\prime \prime} \mathrm{N}$, $87^{\circ} 42^{\prime} 52^{\prime \prime}$ E, 2,205 m a.s.1., in moss, 31 July 2020, 


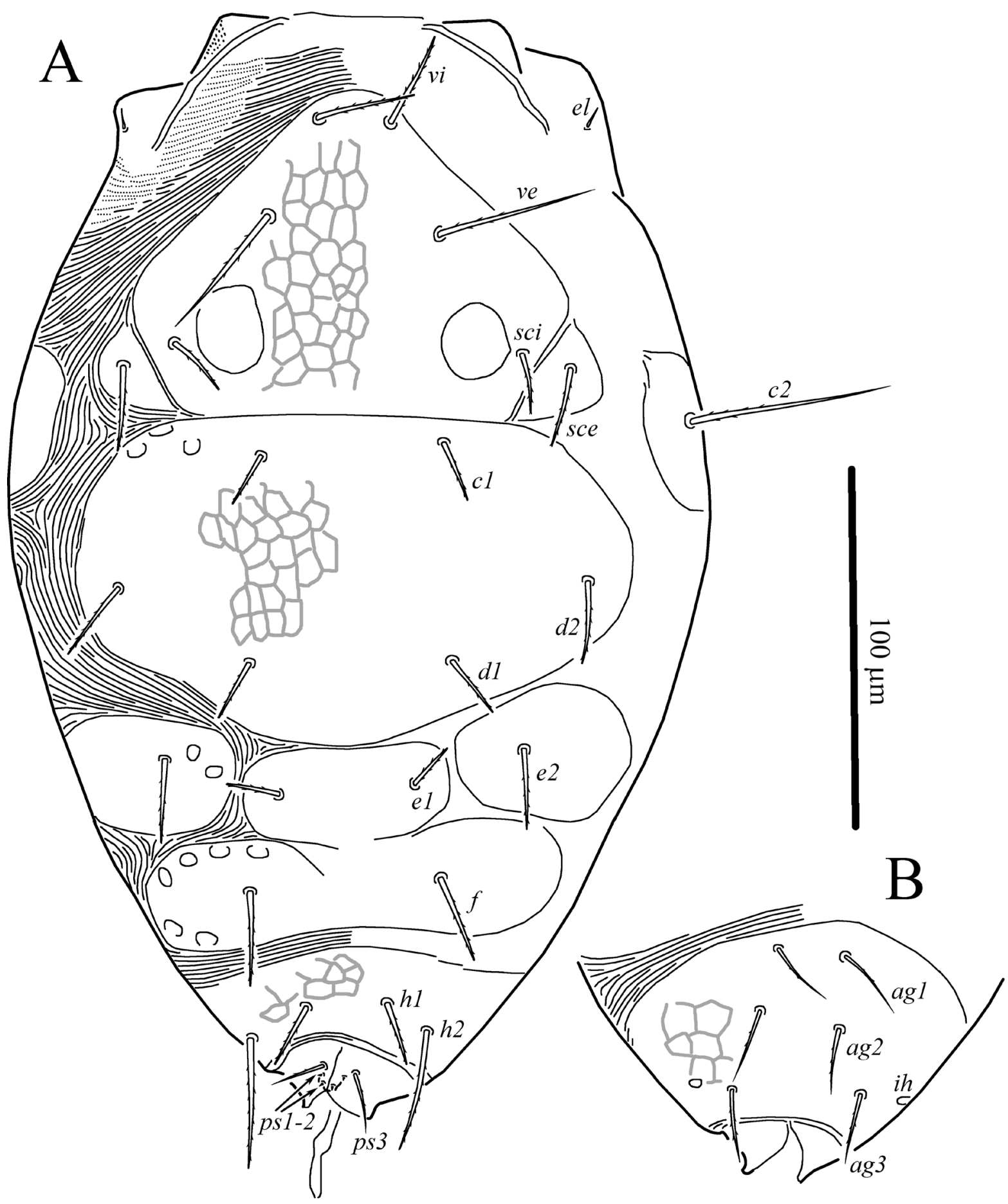

Fig. 5. Stigmaeus akimovi sp.n., male: A-dorsum of idiosoma, B-venter of opisthosoma.

coll. A.A. Khaustov; paratypes: 4 females, 2 males, same data.

Etymology. The new species is named after the late Ukrainian acarologist and former head of the Schmalhausen Institute of Zoology (Kyiv, Ukraine), Igor Akimov, for his contribution to acarology.

Differential diagnosis. The new species is most similar to $S$. dignus Kuznetsov, 1978 in having the same idiosomal, gnathosomal and leg seta- tion; the same shape and structure of dorsal idiosomal shields; presence of striae with microtubercles anterolaterad prodorsal shield; and similar lengths of solenidia and setae $k$ on legs. The new species differs from $S$. dignus in having much smaller postocular bodies without reticulate microsculpture. In particular, the diameter of postocular bodies in S. akimovi is shorter than the distance between median margins of postocular 


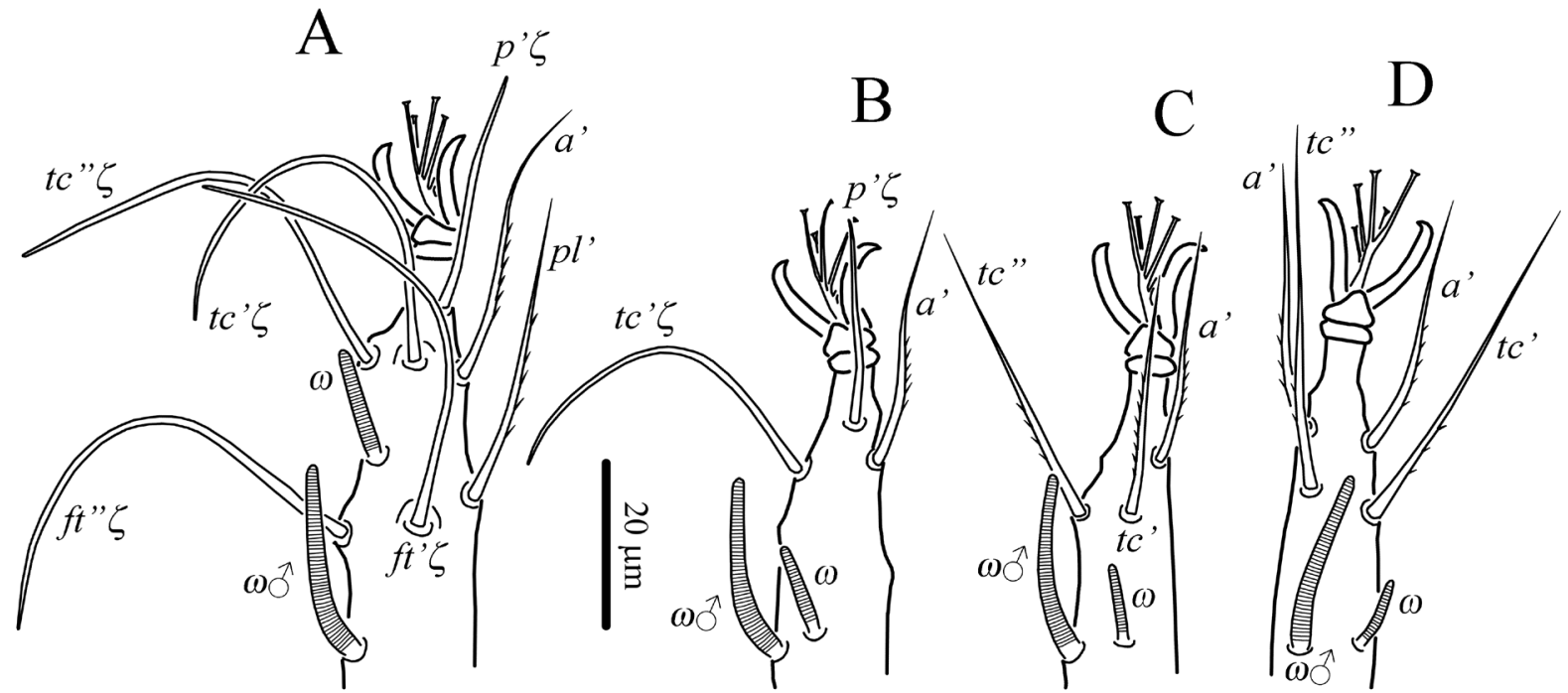

Fig. 6. Stigmaeus akimovi sp.n., male: A-D_tarsi I-IV, dorsal aspect. Ventral setae not illustrated.

bodies ( $v s$. diameter of postocular bodies about twice as long as the distance between median margins of postocular bodies and postocular bodies with weak reticulate microsculpture in $S$. dignus); and in having seta $d$ of palpfemur weakly blunttipped (vs. pointed in S. dignus).

\section{Stigmaeus purpuraecens Summers, 1962}

Stigmaeus purpurascens Summers, 1962: 515

This species was described from the USA(Summers 1962). It was also recorded in Ukraine, Slovakia and Russia (including Western Siberia) (Khaustov 2015; Beron 2020). This article presents the first record of S. purpurascens from the Altai Republic.

Material examined. One female, $1 \mathrm{DN}$, Ulagansk District, $50^{\circ} 18^{\prime} 0.45^{\prime \prime} \mathrm{N}, 87^{\circ} 42^{\prime} 12.3^{\prime \prime} \mathrm{E}$, 2,060 m a.s.1., in grassy soil, 31 July 2020, coll. A. A. Khaustov; 1 DN, Ongudaysk District, $50^{\circ} 24^{\prime} 06^{\prime \prime} \mathrm{N}, 86^{\circ} 40^{\prime} 21^{\prime \prime} \mathrm{E}, 815 \mathrm{~m}$ a.s.1., in moss on soil, 29 July 2020, coll. A.A. Khaustov.

\section{Stigmaeus delaramae Khanjani, 2014}

Stigmaeus delaramae, Khanjani et al. 2014: 371

This species was described from Iran (Khanjani et al. 2014). It was also recorded and redescribed from Greece (Stathakis et al. 2019). In Russia, it was recorded from the Tyumen Region (Khaustov 2015). This article presents the first record of $S$. delaramae from the Altai Republic.

Material examined. Three females, southern part of Lake Tyletskoye, $51^{\circ} 21^{\prime} 34^{\prime \prime} \mathrm{N}, 87^{\circ} 45^{\prime} 52^{\prime \prime}$ $\mathrm{E}$, in moss on lake shore, $430 \mathrm{~m}$ a.s.1., 2 August 2020, coll. A. A. Khaustov.

\section{Stigmaeus longipilis (Canestrini, 1889)}

Stigmaeodes elongatus var. longipilis Canestrini, 1889: 449

Stigmaeus (Stigmaeus) longipilis: Berlese, 1910: 205

Storchia longipilis: Oudemans, 1923: 150

Stigmaeus longipilis: Oudemans, 1927: 263

Stigmaeus eutrichus Berlese, 1910: 206, syn. by Wood 1973: 80

This species is widely distributed in the Holarctic and was recorded from Austria, Azerbaijan, Canada, the Czech Republic, Estonia, Germany, Greece, Greenland, Iran, Italy, Latvia, Lithuania, Moldavia, Poland, Russia, Slovakia, Switzerland, Turkey, Ukraine, and the USA (Beron 2020). In Russia, it was recorded from the European part and from Western Siberia (Khaustov 2015). This is the first record of $S$. longipilis from the Altai Republic.

Material examined. 16 females, Ulagansk District, $50^{\circ} 18^{\prime} 56^{\prime \prime} \mathrm{N}, 87^{\circ} 42^{\prime} 52^{\prime \prime}$ E, 2, $205 \mathrm{~m}$ a. s.1., in moss, 31 July 2020, coll. A. A. Khaustov.

\section{Stigmaeus sphagneti (Hull, 1918)}

Raphignathus sphagneti Hull, 1918: 30

Ledermülleria sphagneti, Oudemans, 1923: 152

Stigmaeus sphagnethi, Summers 1962: 503

This species is widely distributed in the Holarctic and was recorded from Canada, England, Estonia, Greece, Iran, Latvia, Lithuania, Moldavia, Poland, Romania, Russia, Slovakia, Spain, Ukraine, and the USA (Beron 2020). In Russia, it was recorded from the European part and from 

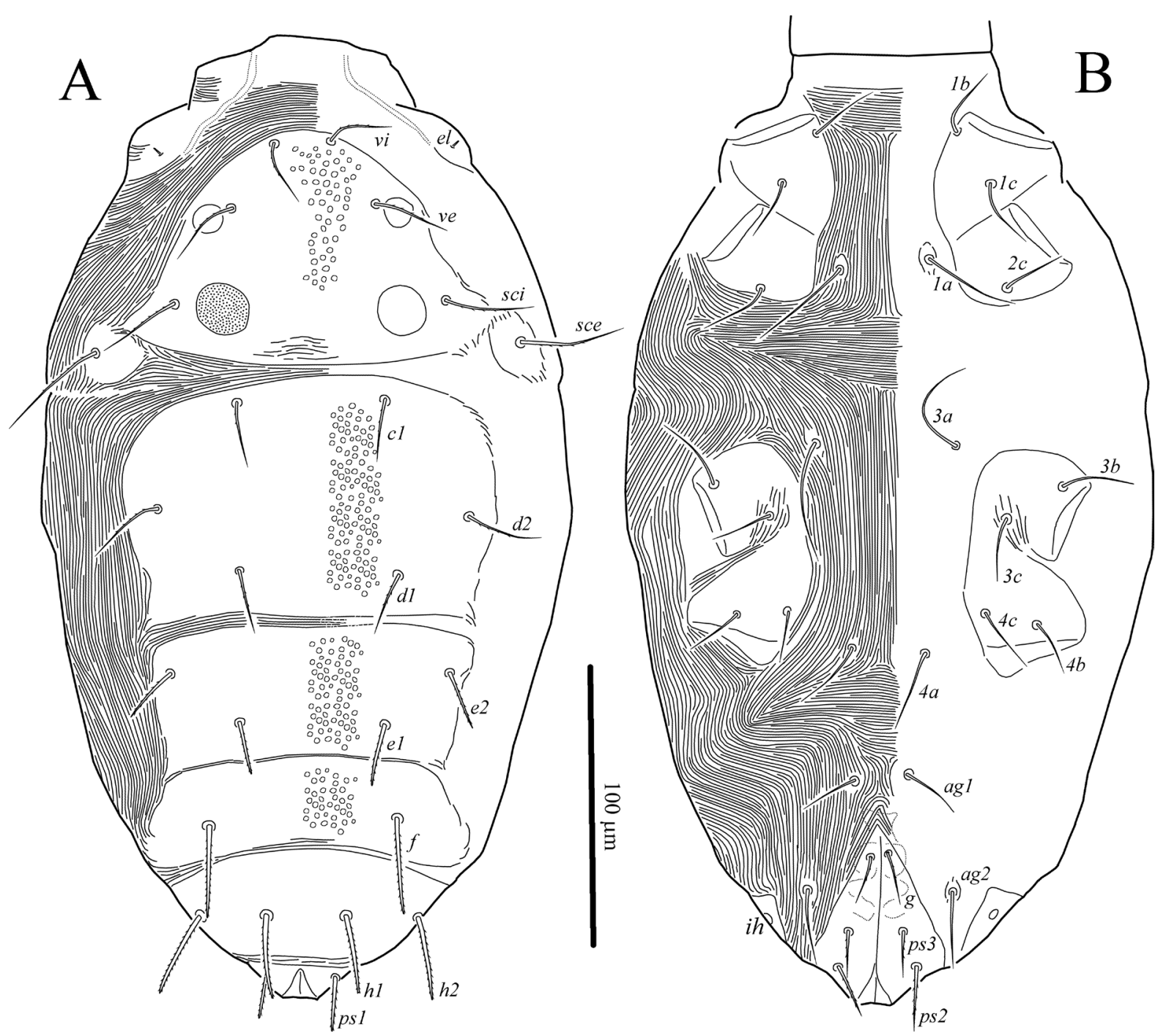

Fig. 7. Mediolata uspenskii Kuznetsov and Sizova, 1978, female: A—dorsum of idiosoma, B-venter of idiosoma.

Western Siberia (Khaustov 2015). This is the first record of $S$. sphagneti from the Altai Republic.

Material examined. Two females, 1 male, Ulagansk District, $50^{\circ} 18^{\prime} 56^{\prime \prime} \mathrm{N}, 87^{\circ} 42^{\prime} 52^{\prime \prime} \mathrm{E}, 2,205 \mathrm{~m}$ a.s.1., in moss, 31 July 2020, coll. A.A. Khaustov.

\section{Genus Mediolata Canestrini, 1889}

Type species: Stigmaeus longirostris Berlese, 1887 , by original designation.

\section{Mediolata uspenskii Kuznetsov and Sizova, 1978}

Mediolata uspenskii Kuznetsov and Sizova, 1978: 61

(Figs. 7-10)

Redescription. Female (Figs. 7-10). Idiosoma fusiform. Length of idiosoma 335, maximum width 185 .
Idiosomal dorsum (Fig. 7A). Prodorsal shield subtriangular, with three pairs of setae $v i$, ve and $s c i$; setae sce situated on separate platelets. Eyes present. Postocular bodies round, with numerous tiny puncta. Hysterosomal dorsum with four shields; anterior shield with three pairs of setae $c 1, d 1$ and $d 2$; second hysterosomal shield with two pairs of setae $e 1$ and $e 2$; third hysterosomal shield with one pair of setae $f$; suranal shield with two pairs of setae $h 1$ and $h 2$. All dorsal shields with poorly visible round dimples. Interscutal striae smooth. All dorsal setae barbed; setae $v i$, ve, sci, sce, $c 1, d 1$ and $d 2$ pointed, other dorsal setae blunt-tipped. Setae ps 1 located dorsally. Ventrolateral parts of suranal shield with poorly visible cupules $i h$. Lengths of dorsal setae: Vi 25, ve 27, sci 32, sce 42, cl 24, $d 124, d 2$ 28, el 23, e2 23,f34, h1 31, h2 32.

Idiosomal venter (Fig. 7B). Endopodal plates reduced. Two pairs of aggenital setae, one pair of 


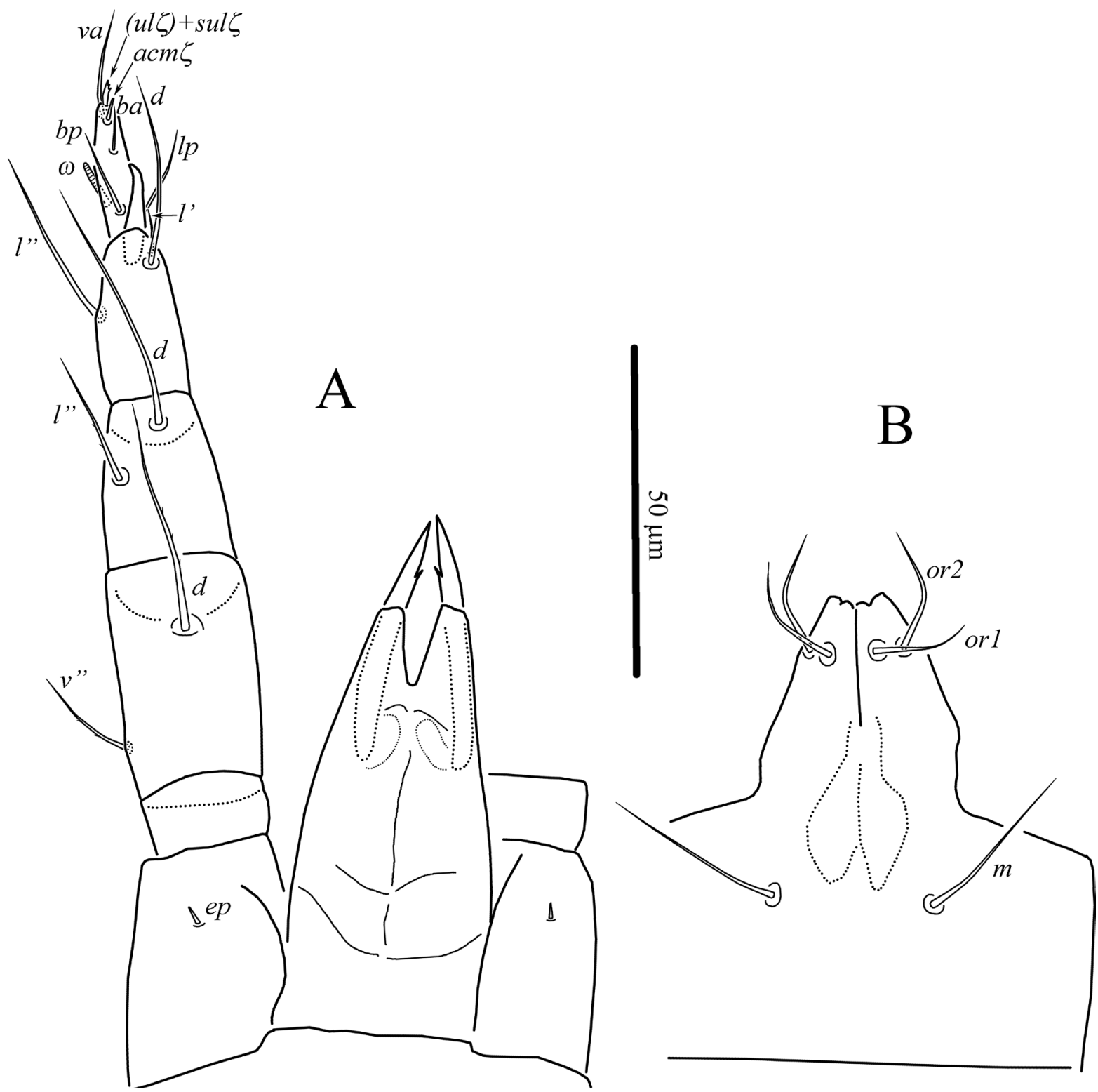

Fig. 8. Mediolata uspenskii Kuznetsov and Sizova, 1978, female: A—gnathosoma, dorsal aspect; B—subcapitulum.

genital setae. All ventral setae pointed; setae $g$ and ps 1-2 weakly barbed, other ventral setae smooth. Lengths of ventral setae: $1 \mathrm{a} 38,1 \mathrm{~b} 25,1 \mathrm{c} 24,2 \mathrm{c}$ 25 , 3a 45, 3b 25, 3c 24, 4a 30, $4 b$ 22, 4c 24, ag 1 23, ag2 27, g 20, ps1 19, ps2 23, ps3 18.

Gnathosoma (Fig. 8). Tibial claw about two times shorter than palptarsus. Setae $l$ ' on palpal tibia setiform. Distal eupathidia $(u l)$ and $s u l$ almost completely fused. All setae of femur, genu and tibia pointed; setae $d, v$ " of palpfemur and $l$ " of palpgenu weakly barbed, other palpal setae smooth. Number of setae on palpal segments: $\operatorname{Tr} 0, \operatorname{Fe} 2(d$, $v$ "), Ge 2 (d, l'), Ti 3 (d, l', l'), Ta 8(1) (fused eupathidia $u l$ ', $u l$ ", sul, eupathidion $a c m, b a, b p$, $l p, 1$ solenidion $\omega)$. Palpal supracoxal setae $(e p)$ short, peg-like. Rostrum of subcapitulum rela- tively long. All subcapitular setae smooth and pointed. Length of subcapitular setae: $m 28$, or 1 16 , or 216 . Length of palps 120 ; length of cheliceral stylets 38 , length of tarsal solenidion $\omega 7$. Cheliceral stylets with distinct subapical tooth.

Legs (Figs. 9, 10). Length of legs: I 180, II 160, III 155, IV 170. Leg segments without reticulation. Empodial raylets with distinctly widened tips. Leg I (Fig. 9A). Coxae I posterodorsally with short peg-like leg supracoxal setae $(e l)$. Leg setation: $\mathrm{Tr}$ $1\left(v^{\prime}\right)$, Fe $4\left(d, l\right.$, $l$ ', $\left.b v^{\prime \prime}\right)$, Ge $2(d, k)$, Ti 5(1) $(d$, l', l', v', v", $\varphi p)$, Ta 11(1) ( $p^{\prime}, p^{\prime \prime}, t c^{\prime}, t c^{\prime \prime}, f t^{\prime}, f t^{\prime \prime}$, $\left.u^{\prime}, u^{\prime \prime}, a^{\prime}, a^{\prime \prime}, v s, \omega\right)$. Setae $k$ of genu, $d$ of tibia and $(p),(t c)$ of tarsus smooth, blunt-tipped, eupathidlike; other setae sparsely barbed and pointed. Seta $k$ 5. Solenidion $\omega 9$ finger-shaped; solenidion $\varphi p$ 


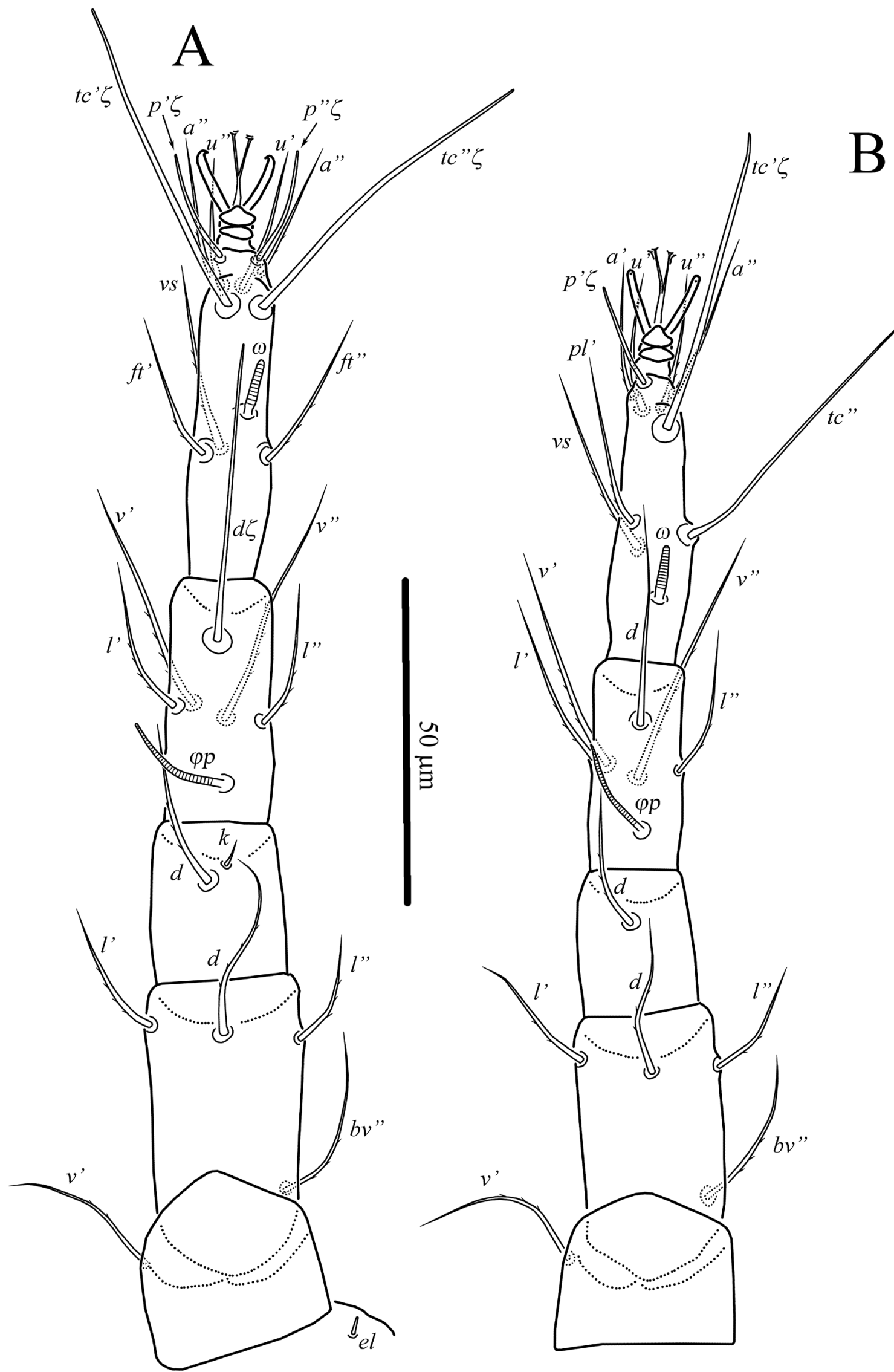

Fig. 9. Mediolata uspenskii Kuznetsov and Sizova, 1978, female: A—right leg I, dorsal aspect; B —right leg II, dorsal aspect. 


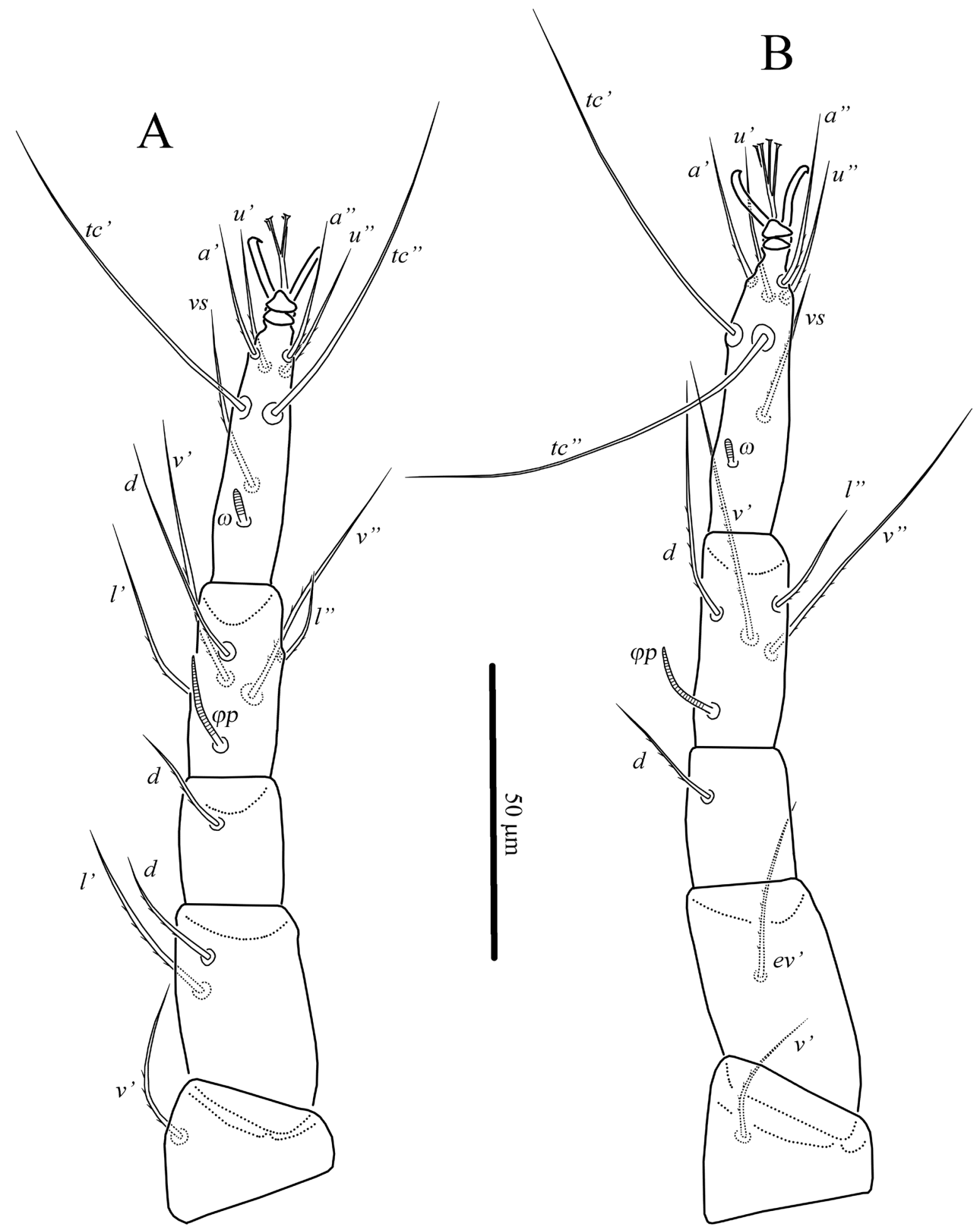

Fig. 10. Mediolata uspenskii Kuznetsov and Sizova, 1978, female: A—right leg III, dorsal aspect; B—right leg IV, dorsal aspect.

18 uniformly thin, with distinctly rounded tip. Leg II (Fig. 9B). Leg setation: $\operatorname{Tr} 1\left(v^{\prime}\right), \mathrm{Fe} 4\left(d, l\right.$, $l^{\prime}$, $\left.b v^{\prime \prime}\right)$, Ge $1(d)$, Ti 5(1) (d, l', l’, v', v', $\left.\varphi p\right)$, Ta 9(1) ( $\left.p^{\prime}, t c^{\prime}, t c^{\prime \prime}, u^{\prime}, u^{\prime \prime}, a^{\prime}, a^{\prime \prime}, p l^{\prime}, v s, \omega\right)$. Setae $p^{\prime}$ and $t c$ ' of tarsus smooth, blunt-tipped, eupathid-like, other setae pointed; setae $d$ of tibia and $t c$ " of tar- sus smooth, other setae (except eupathidia) barbed. Solenidion $\omega 8$ finger-shaped; solenidion $\varphi p 17$ uniformly thin, with distinctly rounded tip. Seta $k$ absent. Leg III (Fig. 10A). Leg setation: Tr 1 ( $\left.v^{\prime}\right)$, Fe $2\left(d, l^{\prime}\right), \operatorname{Ge} 1(d)$, Ti 5(1) (d, l', l', $\left.v^{\prime}, v^{\prime \prime}, \varphi p\right)$, Ta 7(1) (tc', $\left.t c^{\prime \prime}, u^{\prime}, u^{\prime \prime}, a^{\prime}, a^{\prime \prime}, v s, \omega\right)$. Solenidion 
$\omega 6$ finger-shaped; solenidion $\varphi p 14$ uniformly thin, with distinctly rounded tip. All setae pointed; setae $(t c)$ of tarsus smooth, other setae barbed. Leg IV (Fig. 10B). Leg setation: Tr $1\left(v^{\prime}\right)$, Fe 1 (ev'), Ge 1 (d), Ti 4(1) (d, l’, $\left.v^{\prime}, v^{\prime \prime}, \varphi p\right)$, Ta 7(1) (tc', tc', $\left.u^{\prime}, u^{\prime \prime}, a^{\prime}, a^{\prime \prime}, v s, \omega\right)$. Solenidion $\omega 5$ finger-shaped; solenidion $\varphi p 15$ uniformly thin, with distinctly rounded tip. All setae pointed; setae (tc) of tarsus smooth, other setae barbed.

Male and immatures unknown.

Material examined. One female, Kosh-Agach District, $50^{\circ} 05^{\prime} 14^{\prime \prime} \mathrm{N}, 88^{\circ} 24^{\prime} 34^{\prime \prime} \mathrm{E}, 1,750 \mathrm{~m}$ a.s.l., in soil, 30 July 2020, coll. A. A. Khaustov.

Remarks. This species was described from Uzbekistan (Kuznetsov and Sizova 1978). This is the first record of M. uspenskii from Russia.

\section{Mediolata pini Canestrini, 1889}

Mediolata pini Canestrini, 1889: 525

Eupalopsis pini: Berlese, 1894: 71(10)

Eupalopsis reticulata Berlese, 1910: 208, syn. by Summers 1960

Eupalopsis pinicola Oudemans, 1923: 149, syn. by Summers 1960

Eupalopsis punctulata Oudemans, 1923: 149, syn. by Summers 1960

This species is widely distributed in the Holarctic and was recorded from Austria, Azerbaijan, Canada, Egypt, Italy, Latvia, Moldavia, Poland, Russia, Switzerland, Turkey, Ukraine and the USA (Beron 2020). In Russia, it was recorded from the European part (Wainstein and Kuznetsov 1978). This article presents the first record of M. pini from the Asian part of Russia.

Material examined. 1 female, Ulagansk District, $50^{\circ} 18^{\prime} 56^{\prime \prime} \mathrm{N}, 87^{\circ} 42^{\prime} 52^{\prime \prime}$ E, 2,205 m a.s.1., in moss, 31 July 2020, coll. A.A. Khaustov; 4 females, 3 males, 1 DN, Ongudaysk District, 50 $24^{\prime} 06^{\prime \prime} \mathrm{N}$, $86^{\circ} 40^{\prime} 21^{\prime \prime}$ E, $815 \mathrm{~m}$ a.s.1., in moss on soil, 29 July 2020, coll. A. A. Khaustov; 8 females, Kosh-Agach district, $50^{\circ} 14^{\prime} 59^{\prime \prime} \mathrm{N}, 87^{\circ} 50^{\prime} 54^{\prime \prime} \mathrm{E}, 1,600 \mathrm{~m}$ a.s.1., in moss, 30 July 2020, coll. A. A. Khaustov; 1 female, Ulagansk District, $51^{\circ} 00^{\prime} 23.8^{\prime \prime} \mathrm{N}, 88^{\circ} 01^{\prime} 41.3^{\prime \prime}$ E, $570 \mathrm{~m}$ a.s.1., in moss, 1 August 2020, coll. A.A. Khaustov; 2 females, Ulagansk District, $51^{\circ} 02^{\prime} 55^{\prime \prime} \mathrm{N}, 85^{\circ} 36^{\prime} 20^{\prime \prime} \mathrm{E}, 1,745 \mathrm{~m}$ a.s.l., in litter under Siberian pine, 2 August 2020, coll. A.A. Khaustov.

\section{Genus Eustigmaeus Berlese, 1910}

Type species: Stigmaeus kermesinus Koch, 1841 , by original designation.

\section{Eustigmaeus summersi sp. $\mathrm{n}$.}

(Figs. 11-14)

Description. Female (Figs. 11-14). Idiosoma ovate. Length of idiosoma 365 (370), maximum width 265 (275).

Idiosomal dorsum (Fig. 11A). Prodorsal and hysterosomal shields almost completely covering dorsal idiosoma. Dorsal idiosomal setae subequal in length, relatively long, sparsely barbed, blunttipped; their tips without hyaline sheaths. Eyes present. Dorsal shields smooth in central part and with round dimples and weak subcuticular reticulations laterally. Cupules ip and ih poorly visible and located ventrally (Fig. 11B). Prodorsal shield with weak incisions anterolaterad eyes. Dorsal hysterosomal shield with two ventrolateral incisions. Suranal shield located ventrally. Length of dorsal setae: vi 50 (53), ve 77 (82), sci 55 (53), sce 63 (66), c1 56 (65), c2 18 (21), d1 64 (69), d2 59 (65), e1 71 (73), e2 59 (61),f70 (77), h1 48 (51), h2 37 (42).

Idiosomal venter (Fig. 11B). With two pairs of callosities between humeral and dorsal shields; major callosity about two times larger than minor; minor callosity located posterolaterad major callosity. Three pairs of aggenital setae. Aggenital plate with weak subcuticular reticulation in central part, other ventral plates with densely distributed puncta. All ventral setae pointed and weakly barbed. Length of ventral setae: $1 a 30$ (32), $1 b 27$ (27), $1 c 29$ (27), $2 b 26$ (25), 2c 20 (21), $3 a 31$ (31), $3 b 21$ (20), 3c 21 (20), 4a 23 (25), $4 b 20$ (21), 4c 21 (22), ag1 18 (20), ag2 18 (20), ag3 18 (22), ps 1 28 (29), ps2 20 (21), ps3 18 (20).

Gnathosoma (Fig. 12). Tibial claw large, slightly longer than palptarsus. Setae $l$ ' on palpal tibia short, with flattened and widened distal part. All setae of femur, genu and tibia and seta $v a$ of tarsus barbed and pointed; other setae of palptarsus smooth. Number of setae on palpal segments: $\mathrm{Tr}$ $0, \operatorname{Fe} 3$ ( $\left.d, l^{\prime}, v^{\prime \prime}\right)$, Ge 2 (d, l'), Ti 3 (d, l', l'), Ta 8(1) (fused eupathidia $u l$ ', $u l$ ', sul, eupathidion $a c m, b a, b p, l p, 1$ solenidion $\omega)$. Palpal supracoxal setae (ep) slightly thickened, with rounded tip. Rostrum of subcapitulum relatively long, with lateral flanges. Subcapitular setae or 2 blunt-tipped, other setae pointed; setae or 1 and or 2 smooth, other setae weakly barbed. Basal part of subcapitulum without distinct reticulation, with densely distributed puncta. Lengths of subcapitular setae: $m 21$ (23), $n 26$ (21), orl 15 (16), or2 15 (15); length of palps 92 (93); length of cheliceral stylets 41 (41); length of tarsal solenidion $\omega 6$ (7). 

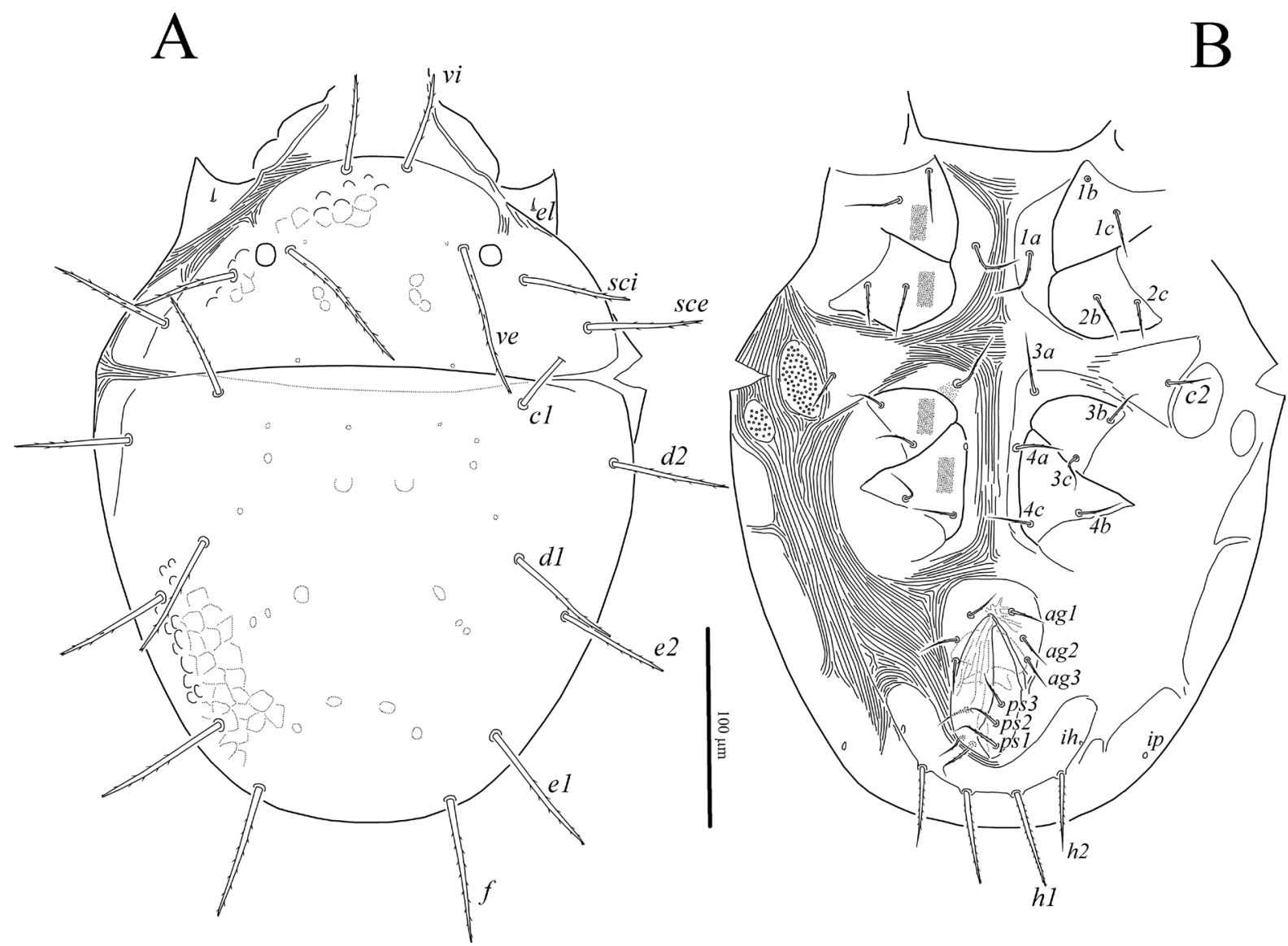

Fig. 11. Eustigmaeus summersi sp.n., female: A—dorsum of idiosoma, B-venter of idiosoma.

Legs (Figs. 13, 14). Length of legs: I 205 (215), II 155 (170), III 150 (150), IV 190 (190). Leg segments without distinct reticulation. Empodial raylets with slightly widened tips. Leg I (Fig. 13A). Coxae I posterodorsally with short leg supracoxal setae (el). Leg setation: $\operatorname{Tr} 1\left(v^{\prime}\right), \operatorname{Fe} 6\left(d, l^{\prime}, l^{\prime \prime}, v^{\prime}\right.$, $\left.v^{\prime \prime}, b v^{\prime \prime}\right), \operatorname{Ge} 4\left(d, l, l^{\prime \prime}, k\right), \operatorname{Ti} 5(2)\left(d, l, l^{\prime \prime}, v^{\prime}, v^{\prime \prime}\right.$, $\varphi, \varphi p)$, Ta 13(1) (p', p', $t c^{\prime}, t c^{\prime \prime}, f t^{\prime}, f t^{\prime \prime}, u^{\prime}, u^{\prime \prime}, a^{\prime}$, $a^{\prime \prime}, p l, p l$ ", $\left.v s, \omega\right)$. Setae $k$ of genu, $d$ of tibia and $(p),(t c),(f t)$ of tarsus smooth, blunt-tipped, eupathid-like; other setae sparsely barbed; setae $d, l$ ' of femur and $d$ of genu weakly blunt-tipped, other setae pointed. Seta $k 12$ (15). Solenidion $\omega 18$ (19), finger-shaped; solenidion $\varphi 12$ (14) baculiform, $\varphi p$ 33 (37) attenuate, with rounded tip. Leg II (Fig. 13B). Leg setation: $\operatorname{Tr} 1$ ( $\left.v^{\prime}\right), \operatorname{Fe} 5$ (d, l', l', $\left.v^{\prime}, b v^{\prime \prime}\right)$, Ge 4 (d, l', l', $k)$, Ti 5(1) (d, l', l’, $\left.v^{\prime}, v^{\prime \prime}, \varphi p\right)$, Ta 9(1) ( $p^{\prime}, t c^{\prime}, t c^{\prime \prime}, u^{\prime}, u^{\prime \prime}, a^{\prime}, a^{\prime \prime}, p l$ ', $\left.v s, \omega\right)$. Setae $k$ of genu, $d$ of tibia, $p^{\prime}$ and $t c^{\prime}$ of tarsus smooth, blunt-tipped, eupathid-like, other setae weakly barbed; setae $d, l$ ', l' of femur and $d$ of genu blunttipped, other setae pointed. Solenidion $\omega 13$ (15) finger-shaped; solenidion $\varphi p 25$ (29) attenuate, with rounded tip. Seta $k$ short 5 (5-6). Leg III (Fig. 14A). Leg setation: $\operatorname{Tr} 2\left(v^{\prime}, l^{\prime}\right), \operatorname{Fe} 3\left(d, l^{\prime}, e v^{\prime}\right), \operatorname{Ge} 1(d)$,
Ti 5(1) (d, l', l’, $\left.v^{\prime}, v^{\prime \prime}, \varphi p\right)$, Ta 7(1) (tc', tc", $u^{\prime}$, $u^{\prime \prime}, a^{\prime}, a$ ", $\left.v s, \omega\right)$. Solenidion $\omega 6$ (8) finger-shaped; solenidion $\varphi p 22$ (26) attenuate, with rounded tip. All setae barbed; setae $d$ of femur and genu blunttipped, other setae pointed. Leg IV (Fig. 14B). Leg setation: $\operatorname{Tr} 1\left(v^{\prime}\right), \mathrm{Fe} 2\left(d, e v^{\prime}\right), \mathrm{Ge} 1(d)$, Ti 5(1) $\left(d, l^{\prime}, l^{\prime \prime}, v^{\prime}, v^{\prime \prime}, \varphi p\right)$, Та 7(1) (tc', tc', $u^{\prime}, u^{\prime \prime}, a^{\prime}$, $a ", v s, \omega)$. Solenidion $\omega 6$ (5) finger-shaped; solenidion $\varphi p 27$ (30) attenuate, with rounded tip. All setae weakly barbed; setae $d$ of femur and genu blunt-tipped, other setae pointed.

Male and immatures unknown.

Type material. Female holotype, slide № AK310720/1, Ulagansk District, 50¹8'56" N, $87^{\circ} 42^{\prime} 52^{\prime \prime}$ E, 2,205 m a.s.1., in moss, 31 July 2020, coll. A.A. Khaustov; paratype: 1 female, same data.

Etymology. The new species is named after American acarologist Francis Summers for his contribution to acarology.

Differential diagnosis. The new species is most similar to E. ottavii (Berlese, 1910) in having the same idiosomal, gnathosomal and leg setation; the same number, shape and locality of callosities. The new species differs from E. ottavii in having distinctly longer dorsal idiosomal setae ve 77-82, 


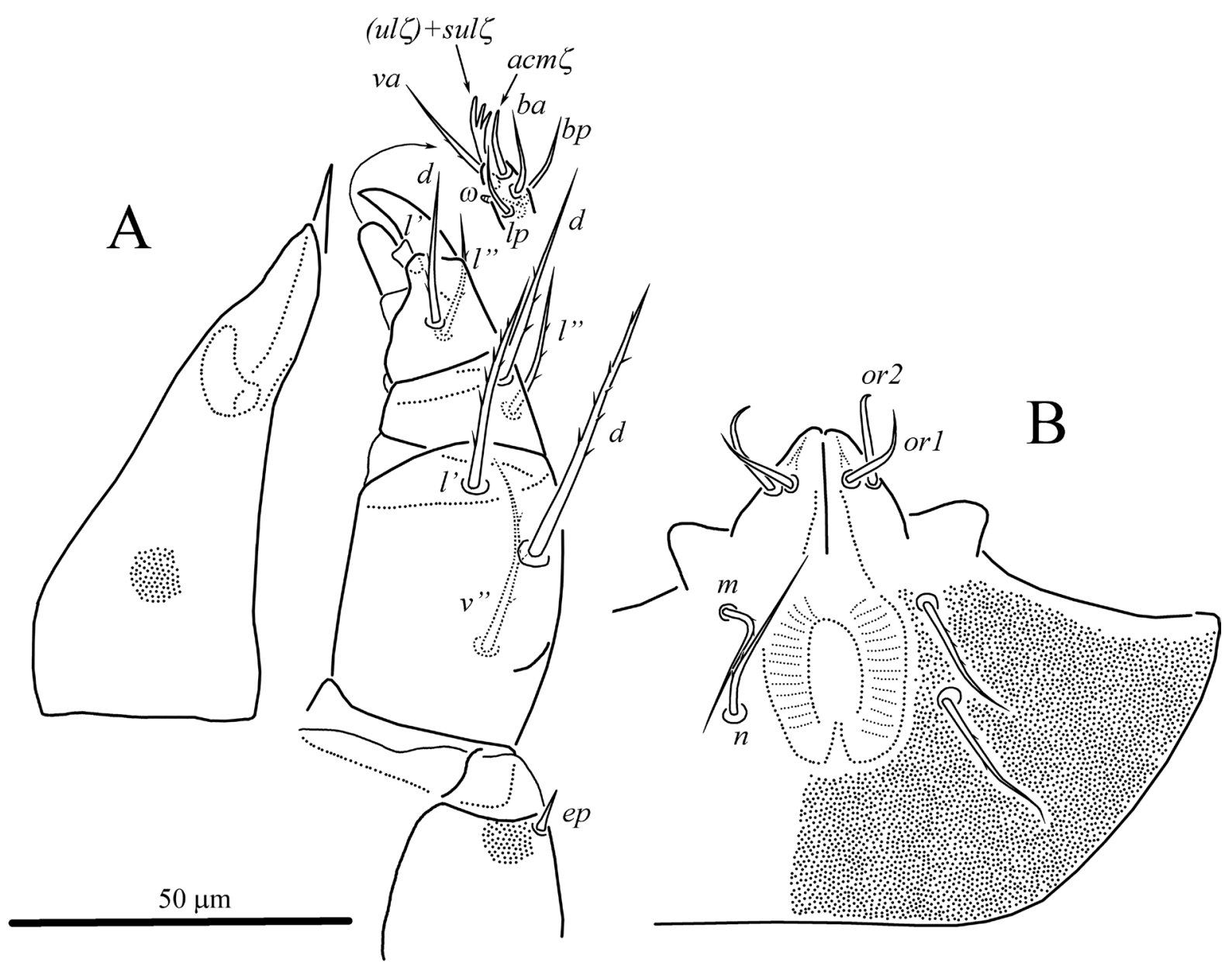

Fig. 12. Eustigmaeus summersi sp.n., female: A—gnathosoma, dorsal aspect; B—subcapitulum.

sce 63-66, c1 56-65, d1 64-69, d2 59-65, e1 71-73, e2 59-61 (ve 55-61, sce 46-51, c1 40-46, d1 42-48, d2 44-53, el 51-59, e2 44-50 in E. ottavii), and in the absence of hyaline sheaths on tips of dorsal idiosomal setae (vs. present in E. ottavii).

\section{Eustigmaeus acidophilus (Wood, 1972)}

Ledermuelleria acidophila Wood, 1972: 309 Eustigmaeus acidophilus (Wood): Wood 1973: 82

(Figs. 15-20)

Description. Female (Figs. 15-18). Idiosoma broadly-ovate. Length of idiosoma 465-505, maximum width 380-420.

Idiosomal dorsum (Fig. 15A). Prodorsal and hysterosomal shields almost completely covering dorsal idiosoma. Dorsal idiosomal setae baculiform, with rounded tips; their tips without distinct hyaline sheaths; most dorsal setae with few weak barbs, except setae $f, h 1$ and $h 2$, which densely barbed; setae $e 2$ very short, smooth. Dorsal shields with distinct round dimples and strong subcuticular reticulation. Eyes present. Suranal shield located ventrally. Length of dorsal setae: vi 35-42, ve 38-42, sci 28-29, sce 21-23, c1 25-27, c2 18-20, d1 25-27, d2 23, el 42-43, e2 7-10,f 53-55, h1 43-49, h2 33-41.

Idiosomal venter (Fig. 15B). With two pairs of subequal elongate callosities located anterolaterad and posterolaterad humeral shield, respectively. Three pairs of aggenital setae. Aggenital plate with weak subcuticular reticulation in lateral parts; anterior endopodal plates with weak reticulation in anterior part; coxal fields I-IV with distinct subcuticular reticulation. All ventral setae pointed; setae ag1-2 and ps 1-3 weakly barbed, other ventral setae smooth. Length of ventral setae: $1 a$ 37-40, 1b 34-36, 1c 30-32, 2b 33-35, 2c 19-22, 3a 41-43, 3b 23-25, 3c 34-36, 4a 28-31, 4b 29-30, 4c 29-31, ag1 21-23, ag2 20-22, ag3 21-24, ps1 19-25, ps2 18-19, ps3 26-27.

Gnathosoma (Fig. 16) partly or completely covered by anterior part of prodorsal shield. Tibial claw large, slightly longer than palptarsus. Setae $l$ ' 


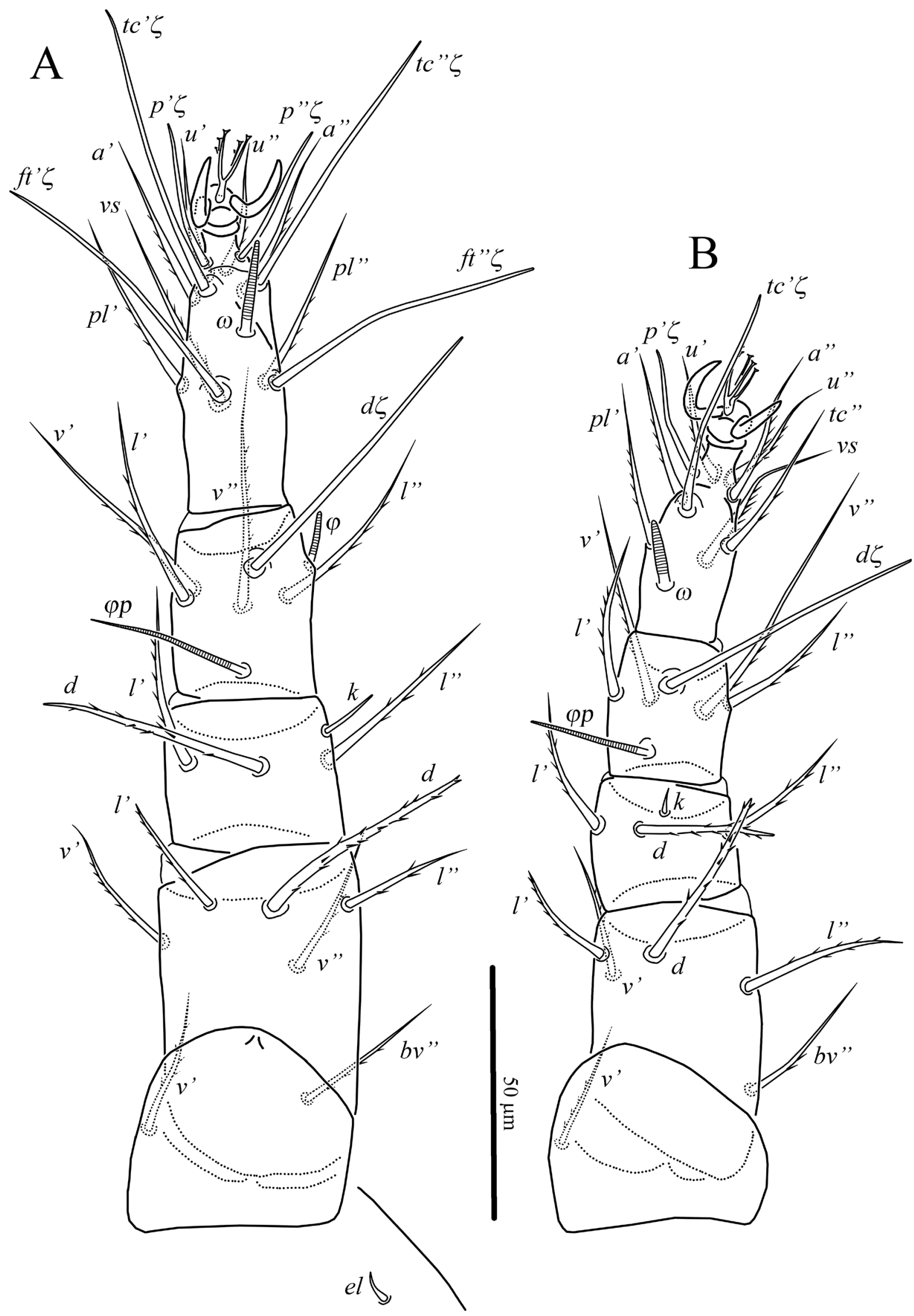

Fig. 13. Eustigmaeus summersi sp.n., female: A—right leg I, dorsal aspect; B—right leg II, dorsal aspect. 


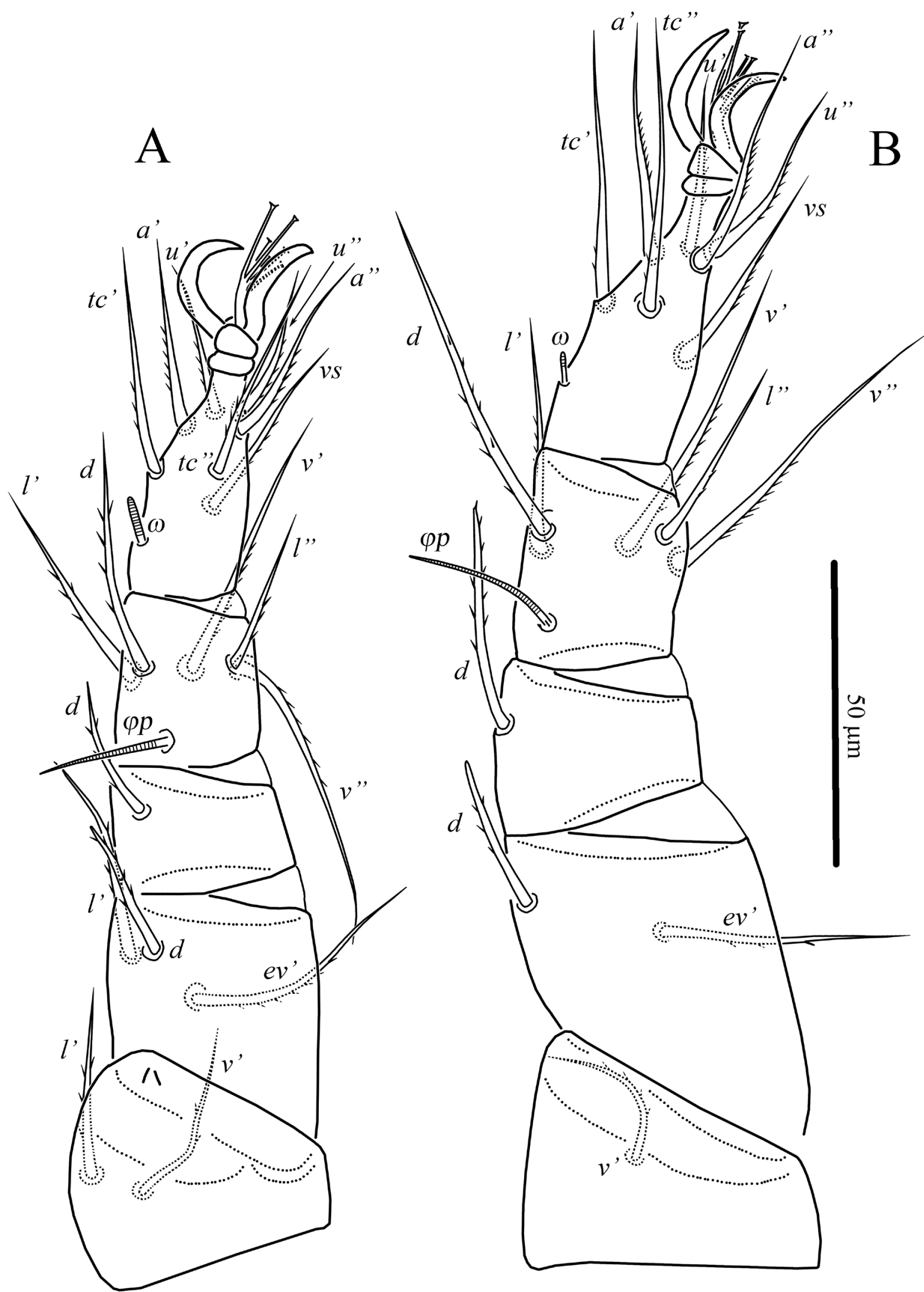

Fig. 14. Eustigmaeus summersi sp.n., female: A—right leg III, dorsal aspect; B—right leg IV, dorsal aspect. 

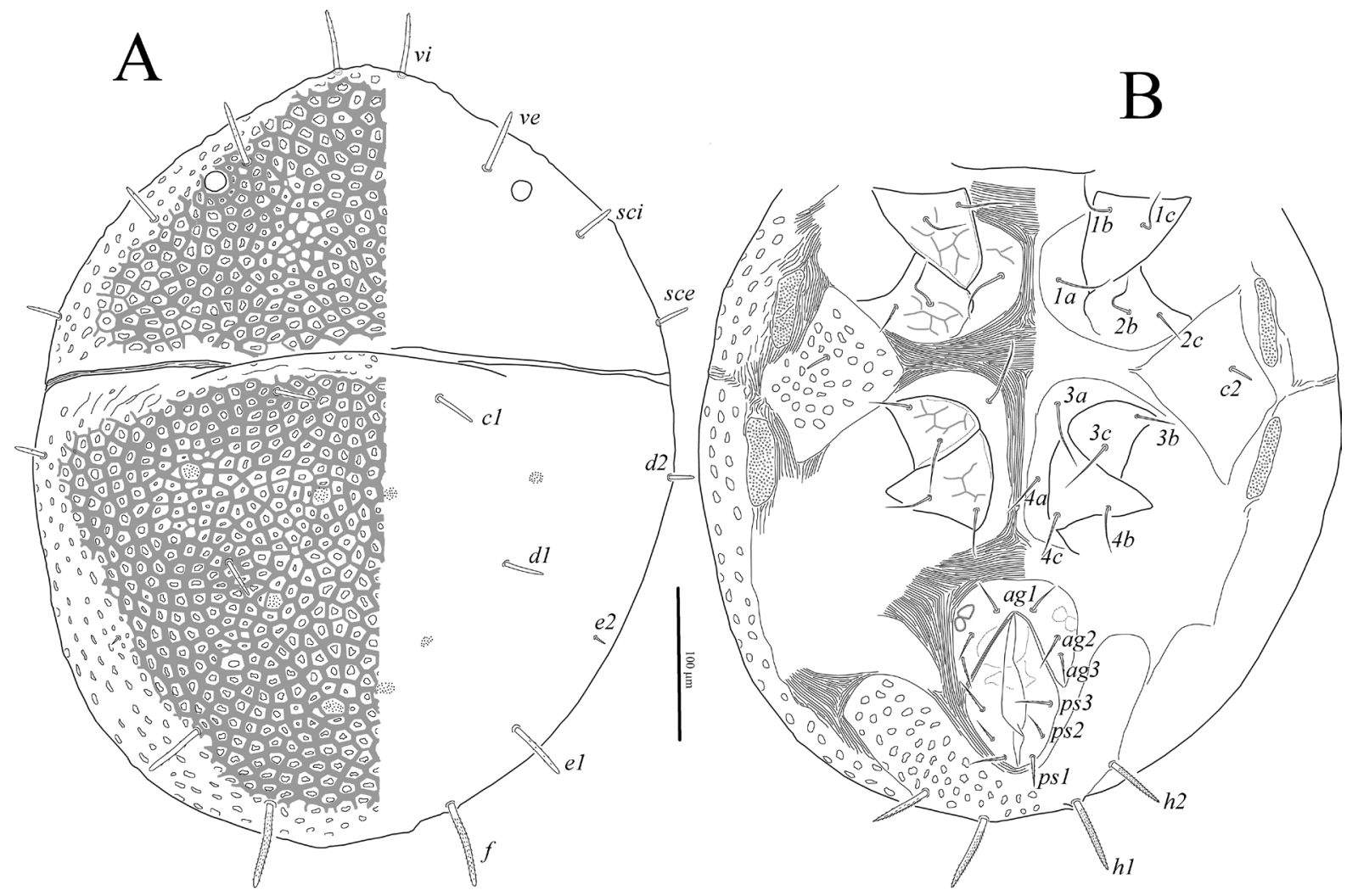

Fig. 15. Eustigmaeus acidophilus (Wood, 1972), female: A—dorsum of idiosoma, B—venter of idiosoma.

on palpal tibia short, spiniform, with rounded tip. All setae of femur, genu, tibia and seta $v a$ of tarsus barbed; other setae of palptarsus smooth; seta $d$ of palpfemur distinctly blunt-tipped. Number of setae on palpal segments: $\operatorname{Tr} 0, \mathrm{Fe} 3\left(d, l^{\prime}, v^{\prime \prime}\right), \operatorname{Ge} 2(d$, $l$ '), Ti 3 (d, l', l'), Ta 8(1) (fused eupathidia $u l$ ', $u l$ ", sul, eupathidion $a c m, b a, b p, l p, 1$ solenidion $\omega)$. Palpal supracoxal setae (ep) slightly thickened, with rounded tip. Rostrum of subcapitulum very long. Subcapitular setae or 1-2 blunt-tipped and smooth, other setae pointed and barbed. Basal part of subcapitulum with subcuticular reticulation and with densely distributed puncta. Lengths of subcapitular setae: $m$ 48-49, $n 38-39$, or $111-12$, or 2 14 ; length of palps 120-130; length of cheliceral stylets 78-81; length of tarsal solenidion $\omega 7-8$.

Legs (Figs. 17, 18). Lengths of legs: I 265-280, II 215-225, III 205-215, IV 225-240. Leg segments without distinct reticulation. Empodial raylets with slightly widened tips. Leg I (Fig. 13A). Coxae I posterodorsally with short leg supracoxal setae (el). Leg setation: Tr $1\left(v^{\prime}\right)$, Fe $6\left(d, l^{\prime}, l^{\prime}\right.$, $\left.v^{\prime}, v^{\prime \prime}, b v^{\prime \prime}\right), \operatorname{Ge} 4$ (d, l', l', $k$ ), Ti 5(2) (d, l', l', v', $\left.v^{\prime \prime}, \varphi, \varphi p\right)$, Ta 13(1) ( $p^{\prime}, p p^{\prime \prime}, t c^{\prime}, t c^{\prime \prime}, f t^{\prime}, f t t^{\prime}, u^{\prime}, u^{\prime \prime}$, $a^{\prime}, a^{\prime \prime}, p l$ ', $p l$ '”, vs, $\left.\omega\right)$. Setae $k$ of genu, $d$ of tibia and $(p),(t c),(f t)$ of tarsus smooth, blunt-tipped, eupathid-like; other setae sparsely barbed; setae $d, l$,' l' of femur, and $d, l$ ', $l$ "' of genu, $l$ ' and $l$ "' of tibia distinctly blunt-tipped, other setae pointed. Seta $k$ 13-15. Solenidion $\omega$ 17-20 finger-shaped; solenidion $\varphi$ 13-14 baculiform, $\varphi p$ 23-26 attenuate, with rounded tip. Leg II (Fig. 17B). Leg setation: $\operatorname{Tr} 1\left(v^{\prime}\right), \mathrm{Fe} 5$ (d, l', l', $\left.v^{\prime}, b v^{\prime \prime}\right), \mathrm{Ge} 4\left(d, l^{\prime}\right.$, $l ”, k)$, Ti 5(1) (d, l', l’, $\left.v^{\prime}, v^{\prime \prime}, \varphi p\right)$, Та 9(1) ( $p^{\prime}$, tc', tc", $\left.u^{\prime}, u^{\prime \prime}, a^{\prime}, a^{\prime}, p l^{\prime}, v s, \omega\right)$. Setae $k$ of genu, $d$ of tibia, $p$ ' and $t c$ ' of tarsus smooth, blunt-tipped, eupathid-like, other setae weakly barbed; setae $d$, $l$ " of femur, $d, l$, $l$ "' of genu and $l$ " of tibia blunttipped, other setae pointed. Solenidion $\omega$ 14-15 finger-shaped; solenidion $\varphi p$ 20-22 attenuate, with rounded tip. Seta $k$ short 7-8. Leg III (Fig. 18A). Leg setation: $\operatorname{Tr} 2\left(v^{\prime}, l^{\prime}\right)$, Fe $3\left(d, l^{\prime}, e v^{\prime}\right)$, Ge 1 (d), Ti 5(1) (d, l', l', v', v', $\varphi p)$, Ta 7(1) (tc', tc", $\left.u^{\prime}, u^{\prime}, a^{\prime}, a^{\prime \prime}, v s, \omega\right)$. Solenidion $\omega 8$ finger-shaped; solenidion $\varphi p$ 16-19 attenuate, with rounded tip. All setae barbed; setae $l$ ' of trochanter, $d, l$ ' of femur, $d$ of genu and $d$ of tibia blunt-tipped, other setae pointed. Leg IV (Fig. 18B). Leg setation: $\mathrm{Tr}$ $1\left(v^{\prime}\right), \operatorname{Fe} 2\left(d, e v^{\prime}\right)$, Ge $1(d)$, Ti 5(1) (d, l', l', $v^{\prime}$, $v^{\prime \prime}, \varphi p$ ), Ta 7(1) (tc', tc”, u', u’, $\left.a^{\prime}, a^{\prime \prime}, v s, \omega\right)$. Solenidion $\omega$ 4-5 weakly clavate; solenidion $\varphi p$ 15-16 attenuate, with rounded tip. All setae weakly barbed; setae $d$ of femur, genu and tibia blunt-tipped, other setae pointed. 


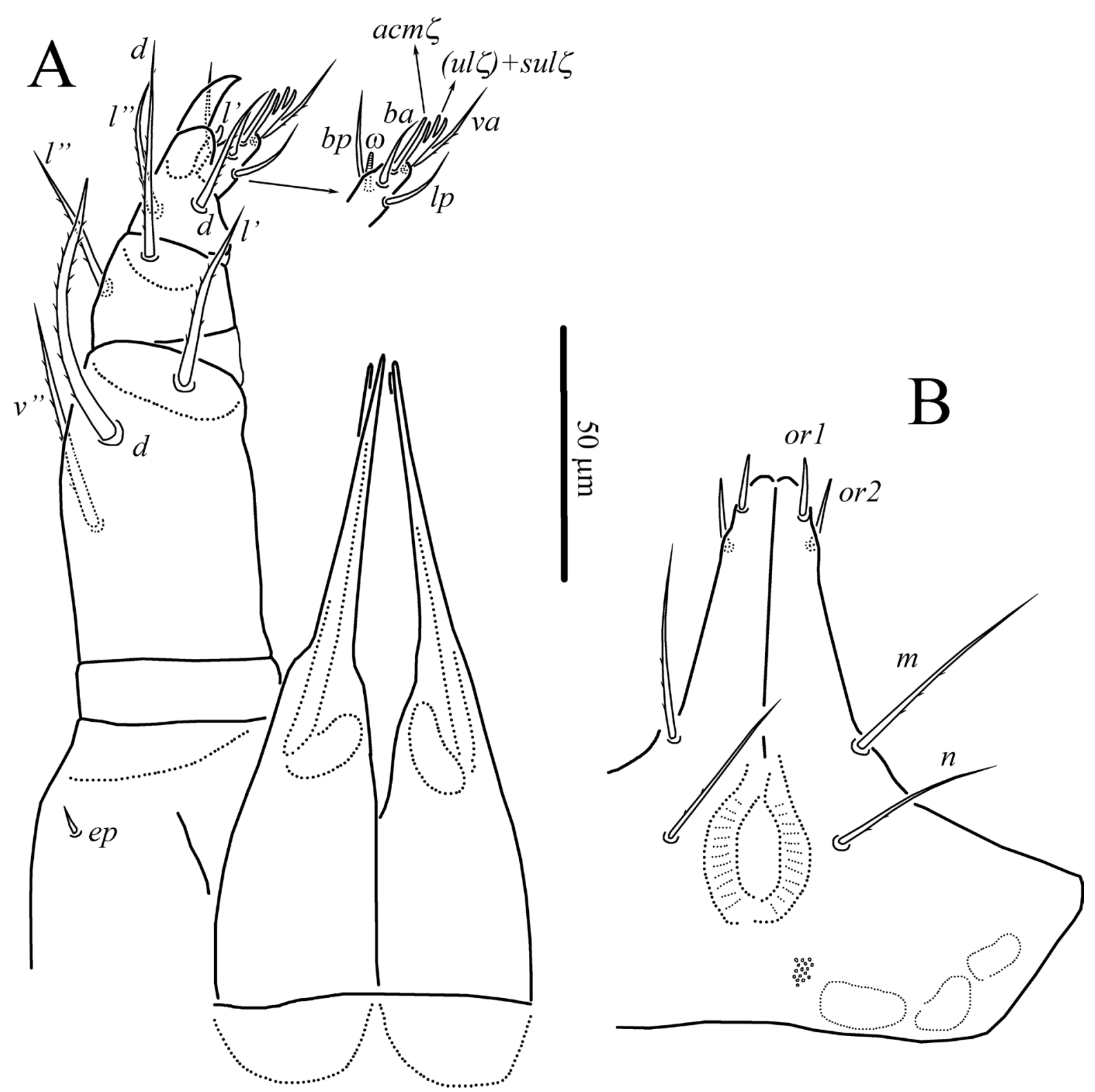

Fig. 16. Eustigmaeus acidophilus (Wood, 1972), female: A—gnathosoma, dorsal aspect; B—subcapitulum.

Male (Figs. 19, 20). Length of idiosoma 330365, width 265-295.

Idiosomal dorsum (Fig. 19A). Podosoma as in female, except presence of weak transverse furrow posteriad setae $d 1$. All dorsal shields with distinct dimples and strong subcuticular reticulation. Setae ps 1-3 located dorsally; setae ps 1-2 small, spiniform, located on distinct protuberance, setae $p s 3$ pointed and smooth, setae $h l$ weakly barbed and pointed; setae $h 2$ densely barbed and pointed. Aedeagus well sclerotized, long, curved. Length of dorsal setae: vi 27-30, ve 30-36, sci 20-21, sce 16-18, cl 20, c2 12-14, d1 19-20, d2 14-15, el 28-36, e2 5-7, f 30-48, h1 14-16, h2 30-40.
Idiosomal venter (Fig. 19B). Opisthosomal venter with two pairs of aggenital setae located on large, weakly reticulated aggenital plate; setae $a g 1$ pointed and weakly barbed, ag2 weakly blunttipped and barbed; cupules ih located anterolaterad bases of setae $a g 2$; podosomal venter as in female. Lengths of ventral setae: $1 a 36,1 b$ 28-36, $1 c$ 2526, $2 b$ 23-29, 2c 16-19, 3a 35, 3b 20, 3c 22-27, $4 a$ 30, 4b 21-24, 4c 28, ag1 21-22, ag2 15-17, ps 1 6, ps2 6, ps3 15-16.

Gnathosoma as in female. Lengths of subcapitular setae: $m$ 41-42, $n$ 30-31, or 110 , or 212 ; length of palps 105-110; length of palpal solenidion $\omega 7$; length of cheliceral stylets 62-66. 


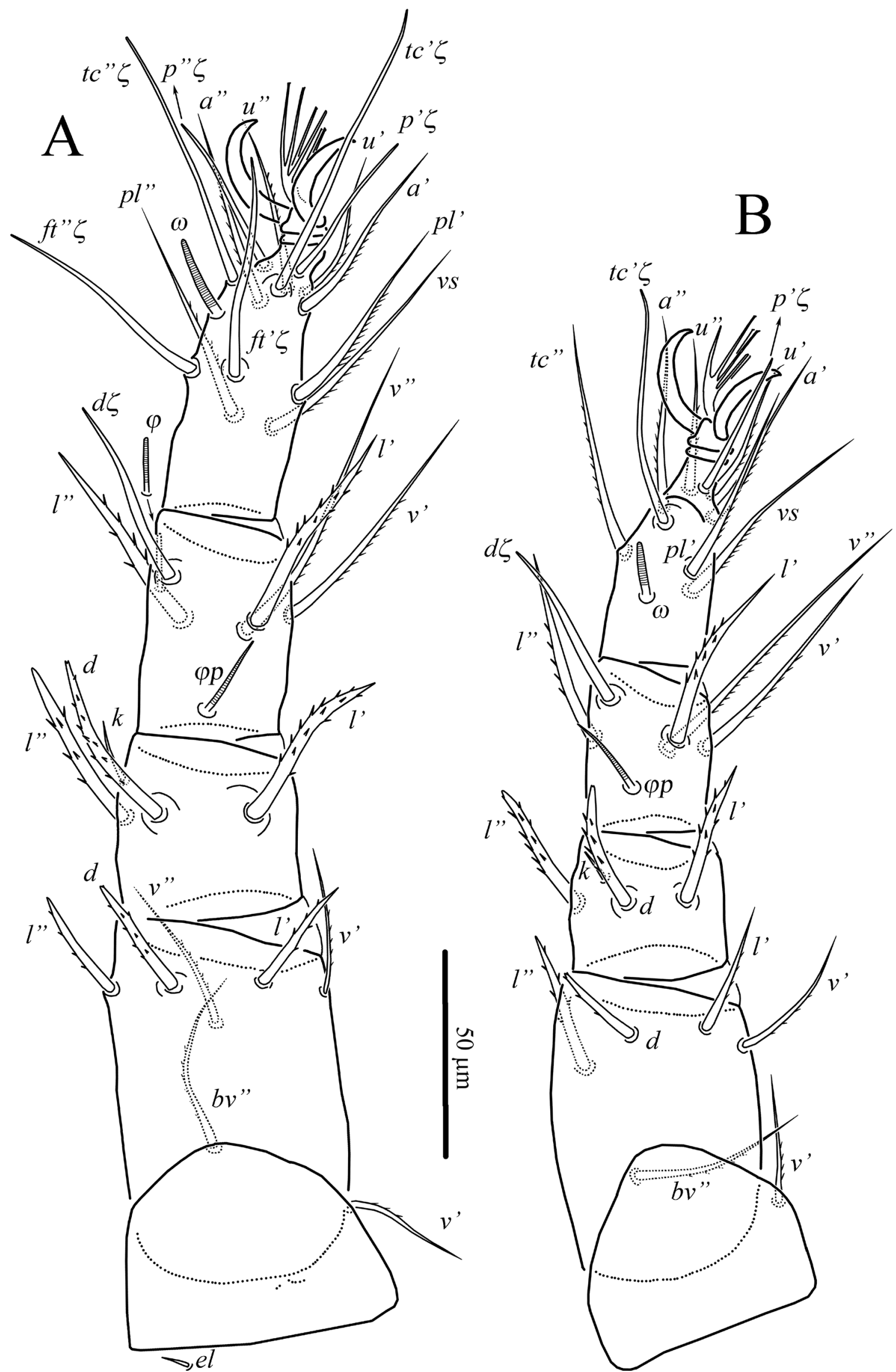

Fig. 17. Eustigmaeus acidophilus (Wood, 1972), female: A—left leg I, dorsal aspect; B—left leg II, dorsal aspect. 

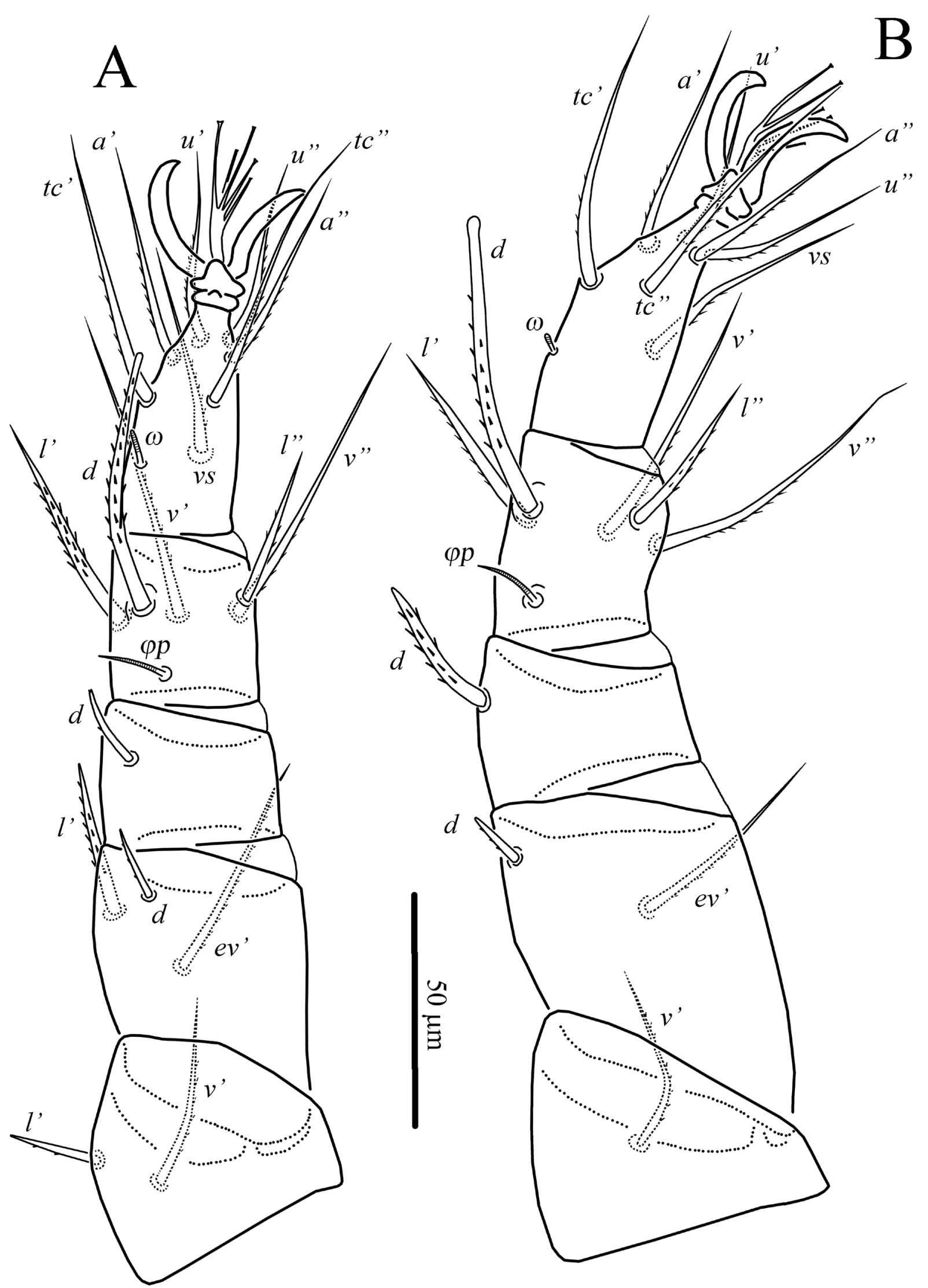

Fig. 18. Eustigmaeus acidophilus (Wood, 1972), female: A—right leg III, dorsal aspect; B—right leg IV, dorsal aspect. 


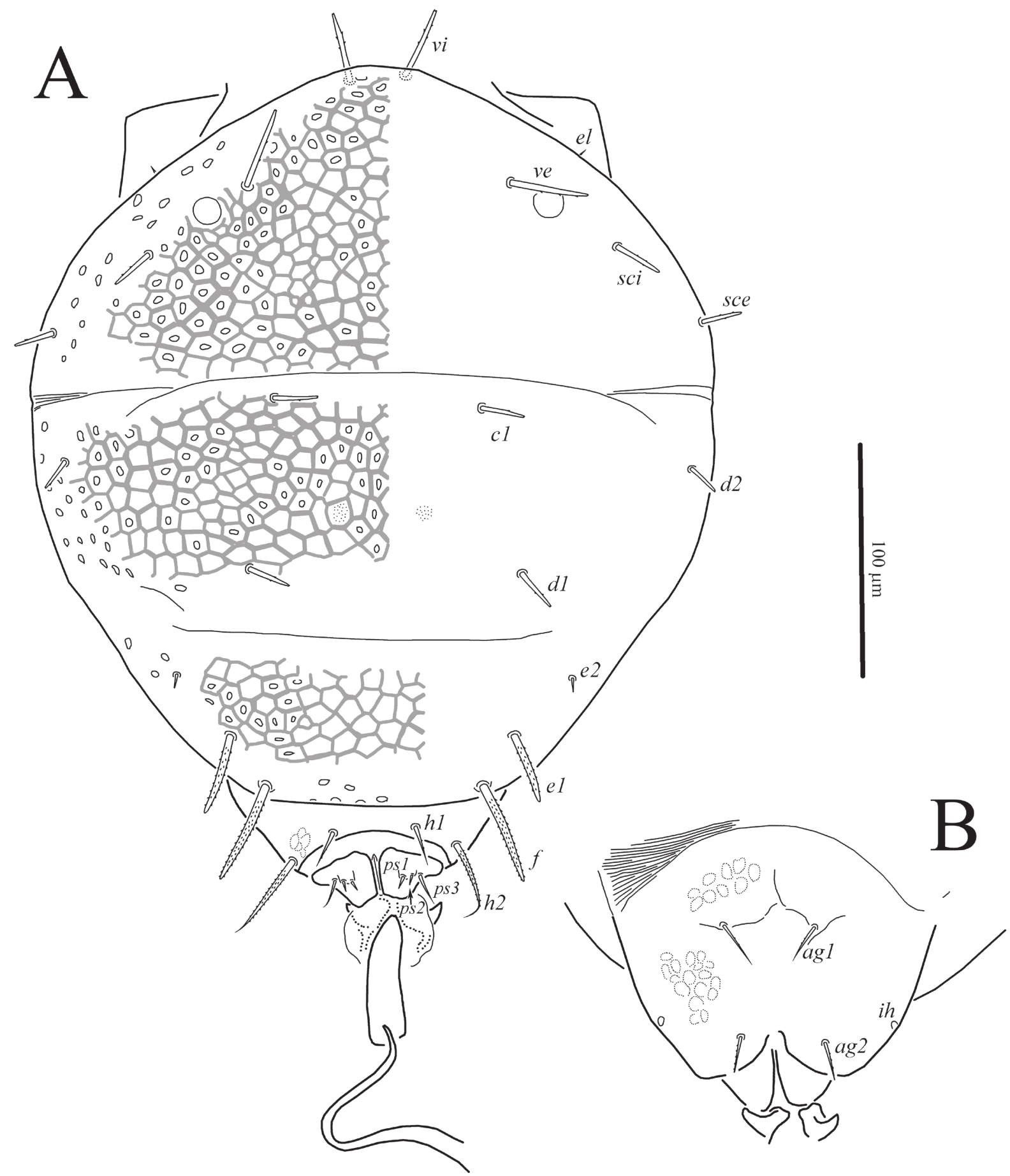

Fig. 19. Eustigmaeus acidophilus (Wood, 1972), male: A—dorsum of idiosoma, B-venter of opisthosoma.

Legs (Fig. 20). Legs as in female, except presence of well-developed male solenidia on tarsi I-IV. One male without seta $v$ ' on femur II on both legs. Lengths of solenidia and setae $k: \omega \mathrm{I} 18-21, \omega{ }^{\lambda} \mathrm{I}$ 35-39, $\varphi \mathrm{I} 11-12, \varphi p \mathrm{I} 22, k \mathrm{I} 12, \omega \mathrm{II} 14-17, \omega{ }^{\lambda} \mathrm{II}$ 32-33, $\varphi p$ III 15, $\omega$ IV 4, $\omega{ }^{\lambda} \mathrm{IV} 28-30, \varphi p \mathrm{IV} 14$.

Immatures unknown.
Material examined. 5 females and 2 males, Ulagansk District, $51^{\circ} 02^{\prime} 55^{\prime \prime} \mathrm{N}, 85^{\circ} 36^{\prime} 20^{\prime \prime} \mathrm{E}, 1,745 \mathrm{~m}$ a.s.l., in moss, 2 August 2020, coll. A.A. Khaustov.

Remarks. This species was described from Canada (Wood 1972). This is the first record of E. acidophilus from the Palaearctic and from Russia. Specimens from Altai agree well with the original description, especially in having unusu- 


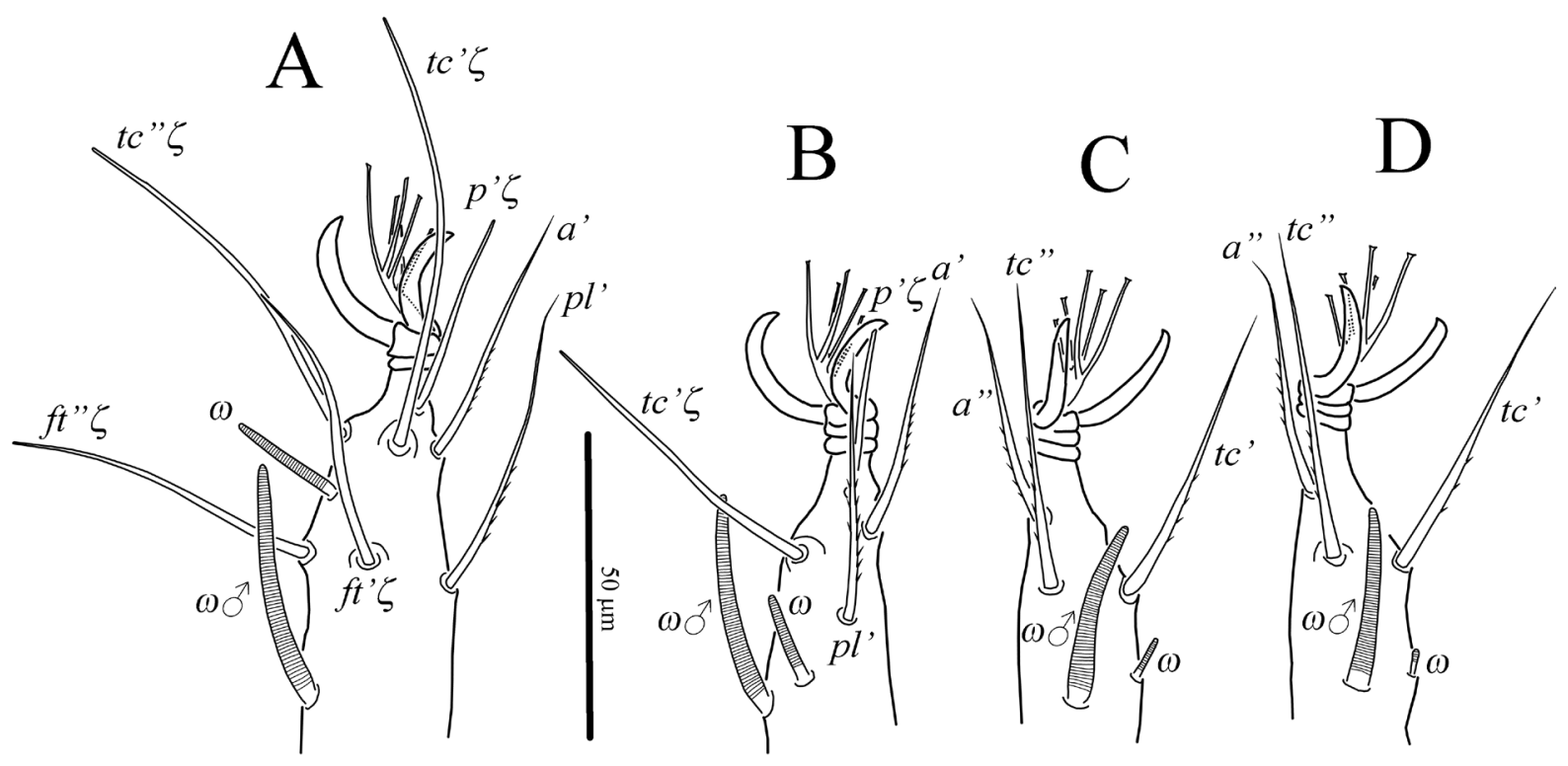

Fig. 20. Eustigmaeus acidophilus (Wood, 1972), male: A-D_tarsi I-IV, dorsal aspect. Ventral setae not illustrated.

ally short setae $e 2$, strongly reticulate dorsal shields and unusually long rostrum of the subcapitulum.

\section{Eustigmaeus parvisetus (Chaudhri, 1965)}

Ledermuelleria parviseta Chaudhri, 1965: 474 Eustigmaeus parvisetus: Wood 1973: 82

This species was described from the USA (Chaudhri 1965). It was also reported and redescribed from Western Siberia, Russia (Khaustov and Tolstikov 2014). This article presents the first record of E. parvisetus from the Altai Republic.

Material examined. 2 females, Ulagansk District, $50^{\circ} 18^{\prime} 56^{\prime \prime} \mathrm{N}, 87^{\circ} 42^{\prime} 52^{\prime \prime}$ E, 2,205 m a.s.1., in moss, 31 July 2020, coll. A. A. Khaustov.

\section{Eustigmaeus segnis (C. L. Koch, 1836)}

Caligonus segnis C.L.Koch, 1836: 5(10)

Raphignathus ruber Koch, 1842: 56

Raphignathus piger Berlese, 1885: fasc. 22(1)

Ledermblleria segnis: Oudemans 1923: 150

Ledermuelleria segnis: Summers 1957: 50

Eustigmaeus segnis: Wood 1973: 87

This species is one of the most abundant ones in the Holarctic. It was recorded from at least 20 countries, including Russia (Beron 2020). This is the first record of E. segnis from the Altai Republic.

Material examined. 1 female, Kosh-Agach District, $50^{\circ} 14^{\prime} 59^{\prime \prime} \mathrm{N}, 87^{\circ} 50^{\prime} 54^{\prime \prime} \mathrm{E}, 1,600 \mathrm{~m}$ a.s. 1 , in moss, 30 July 2020, coll. A. A. Khaustov; 4 females, 2 males, 3 DN, Ulagansk District, $51^{\circ} 00^{\prime} 23.8^{\prime \prime}$ $\mathrm{N}, 88^{\circ} 01^{\prime} 41.3^{\prime \prime}$ E, $570 \mathrm{~m}$ a.s.1., in moss, 1 August
2020, coll. A.A. Khaustov; 2 females, 1 male, 1 DN, Ulagansk District, $51^{\circ} 14^{\prime} 28^{\prime \prime} \mathrm{N}, 87^{\circ} 41^{\prime} 57^{\prime \prime}$ E, $1,535 \mathrm{~m}$ a.s.1., in soil, 30 July 2020 , coll. A.A. Khaustov; 1 male, 2 DN, Kosh-Agach District, $50^{\circ} 05^{\prime} 14^{\prime \prime} \mathrm{N}, 88^{\circ} 24^{\prime} 34^{\prime \prime} \mathrm{E}, 1,750 \mathrm{~m}$ a.s.1., in soil, 30 July 2020, coll. A. A. Khaustov.

\section{Eustigmaeus rhodomelus (C.L. Koch, 1841)}

Celaeno rhodomela C.L. Koch, 1841: 2

Raphignathus patrius Berlese, 1885: 4

Ledermuelleria rhodomela: Summers and Price 1961: 377

Eustigmaeus rhodomela: Wood 1973

Eustigmaeus fani Doğan, 2005: 854, syn. by Faraji, Ueckermann and Bakker 2007

Eustigmaeus rhodomelus: Kapaxidi and Papadoulis 1999: 143

This species is widely distributed in the Holarctic region. It was reported from Canada, Germany, Greece, Iran, Italy, Moldavia, Poland, Turkey, the USA and European Russia (Beron 2020). This is the first record of E. rhodomelus from the Asian part of Russia.

Material examined. 4 females, 5 males, $4 \mathrm{PN}$, 4 DN, Ulagansk District, $50^{\circ} 19^{\prime} 07.4^{\prime \prime} \mathrm{N}, 87^{\circ} 44^{\prime} 32.7^{\prime \prime}$ E, 2,320 $\mathrm{m}$ a.s.1., in wet moss near a stream, 31 July 2020, coll. A.A. Khaustov.

\section{Genus Cheylostigmaeus Willmann, 1951}

Type species: Cheylostigmaeus grandiceps Willmann, 1951, by original designation. 


\section{Cheylostigmaeus sp.}

The genus Cheylostigmaeus currently includes 34 described species. Most Cheylostigmaeus species are hardly distnguishable based on females: males are necessary for correct identification. I collected only females and immatures of Cheylostigmaeus sp.

Material examined. Four females, 7 PN, 8 DN, Kosh-Agach District, 50 05'14" N, 88 $24^{\prime} 34^{\prime \prime}$ E, $1,750 \mathrm{~m}$ a.s.1., in soil, 30 July 2020, coll. A.A. Khaustov.

\section{ACKNOWLEDGEMENTS}

This research was supported by the Russian Science Foundation, grant № 20-64-47015.

\section{REFERENCES}

Berlese, A. 1885. Acarorum systematis specimen. Bolletino della Societad Entomologica Italiana, 17: 121-135.

Berlese, A. 1894. Acari, Myriopoda et Scorpiones hucusque in Italia reperta. Ordo Prostigmata (Trombidiidae). Patavii, Sumptibus auctoris, Volumen VIII, Fasc. LXXI-LXXX.

Berlese, A. 1910. Acari nuovi. Manipulus V. Redia, 6: 199-214.

Beron, P. 2020. Acarorum catalogus VII: Trombidiformes, Prostigmata, Raphignathoidea (Fam. Barbutiidae, Caligonellidae, Camerobiidae, Cryptognathidae, Dasythyreidae, Dytiscacaridae, Eupalopsellidae, Homocaligidae, Mecognathidae, Raphignathidae, Stigmaeidae, Xenocaligonellididae). Pensoft, National Museum of Natural History, Sofia, Bulgarian Academy of Sciences, Sofia, $306 \mathrm{pp}$.

Canestrini, G. 1889. Prospetta dell' Acarofouna Italiana, Famiglia dei Tetranychini. Atti Reale Istituto Veneto di Scienze, Lettere ed Arti, 6: 591-537.

Chaudhri, W.M. 1965. New mites of the genus Ledermuelleria. Acarologia, 7: 467-486.

Doğan, S. 2005. Eustigmaeus mites from Turkey (Acari: Stigmaeidae). Journal of Natural History, 39: 835-861.

Fan, Q.-H., Flechtmann C.H.W. and De Moraes, G.J. 2016. Annotated catalogue of Stigmaeidae (Acari: Prostigmata), with a pictorial key to genera. Zootaxa, 4176: 1-199.

Fan, Q.-H., Flechtmann C.H.W. and De Moraes, G.J. 2019. Emendations and updates to "Annotated catalogue of Stigmaeidae (Acari: Prostigmata), with a pictorial key to genera". Zootaxa, 4647: 88-103.

Faraji, F., Ueckermann, E.A. and Bakker, F. 2007. First record of Eustigmaeus jiangxiensis $\mathrm{Hu}$, Chen and
Huang (Acari: Stigmaeidae) from France with a key to the European species of Eustigmaeus Berlese, 1910. International Journal of Acarology, 33: 145-151.

Gerson, U., Smiley, R.L. and Ochoa, R. 2003. Mites (Acari) for Pest Control. Blackwell Science, 540 pp.

Grandjean, F. 1939. Les segments postlarvaires de l'hysterosoma chez les oribates (Acariens). Bulletin Societe Zoology France, 64: 273-284.

Grandjean, F. 1944. Observations sur les Acariens de la famille des Stigmaeidae. Archives des Sciences Physiques et Naturelles, 26: 103-131.

Grandjean, F. 1946. Au sujet de l'organe de Claparède, des eupathides multiples et des taenidies mandibulaires chez les Acariens actinochitineux. Archives des Sciences Physiques et Naturelles, 28: 63-87.

Hull, J.E. 1918. Terrestrial Acari of the Tyne Province. Transactions of the Natural History Society of Northumbria, 5: 13-88.

Kapaxidi, E.V. and Papadoulis, G.Th. 1999. New records of stigmaeid mites from Greece with description of a new species (Acari: Stigmaeidae). International Journal of Acarology, 25: 141-144.

Kethley, J.B. 1990. Acarina: Prostigmata (Actinedida). In: D.L. Dindal (Ed.). Soil Biology Guide. Wiley, New York, pp. 667-756.

Khanjani, M., Nasrollahi, S., Zamani, A.S. and Fayaz, B.A. 2014. Cheylostigmaeus tarae sp. nov. and Stigmaeus delaramae sp. nov. (Acari: Stigmaeidae) from Kurdistan, Iran. Zootaxa, 3841: 364-378.

Khaustov, A.A. 2014. A new species of the genus Paravillersia (Acari: Prostigmata: Stigmaeidae) from Western Siberia, with supplementary description of Paravillersia grata Kuznetsov, 1978. Zootaxa, 3873: 62-72.

Khaustov, A.A. 2015. New species and new records of mites of the genus Stigmaeus (Acari: Prostigmata: Stigmaeidae) from Western Siberia with redescription of S. livschitzi Kuznetsov, 1977. Systematic and Applied Acarology, 20 (6): 681-692.

Khaustov, A.A. 2016. Two new species and a new record of mites of the family Stigmaeidae (Acari: Prostigmata) collected from mosses in Russia. Acarologia, 56: 321-339.

Khaustov, A.A. 2020. New records of predatory mites of the genus Stigmaeus (Acari: Prostigmata: Stigmaeidae) from Western Siberia with the redescriptions of S. dingus Kuznetsov and S. uzunolukensis Özçelik and Doğan. Acarina, 28: 177-191.

Khaustov, A.A. 2021. A new species and a new record of Stigmaeus (Acari: Prostigmata: Stigmaeidae) from Western Siberia, Russia. International Journal of Acarology, 47: 248-261. 
Khaustov, A. A. and Abramov, V. V. 2017. A new species and a new record of raphignathoid mites (Acari: Raphignathoidea: Camerobiidae, Stigmaeidae) occurring in the galleries of bark beetles (Coleoptera: Curculionidae: Scolytinae) from Russia. Systematic and Applied Acarology, 22: 1385-1398.

Khaustov, A.A. and Tolstikov A.V. 2014. A new species and new records of the genus Eustigmaeus (Acari: Prostigmata: Stigmaeidae) from Western Siberia. Zootaxa, 3861: 531-553.

Koch, C.L. 1836-1842. Deutschland Crustaceen, Myriapoden und Arachniden. Regensburg.

Kuznetsov, N.N. and Sizova, I.Yu. 1978. K faune khishnykh kleschey khlopkovykh polei Uzbekistana [On the fauna of predatory mites of cotton field of Uzbekistan]. Uzbekskii Biologicheskiy Zhurnal, 4: 59-64. [In Russian]

Oudemans, A.C. 1923. Acarologische Aanteekeningen LXXI. Entomologische Berichten, 6: 145-155.

Oudemans A.C. 1927. Acarologische Aanteekeningen LXXXVIII. Entomologische Berichten, 7: 257-268.

Stathakis, T.I., Kapaxidi E.V. and Papadoulis, G.Th. 2019. The genus Stigmaeus Koch (Acari: Stigmaei- dae) from Greece. Systematic and Applied Acarology, 24: 2010-2093.

Summers, F.M. 1957. American species of Ledermuelleria and Ledermuelleriopsis, with a note on new synonymy in Neognathus (Acarina, Stigmaeidae, Caligonellidae). Proceedings of the Entomological Society of Washington, 59: 49-60.

Summers, F.M. 1962. The genus Stigmaeus (Acarina: Stigmaeidae). Hilgardia, 33: 491-537.

Summers, F.M. and Price, D.W. 1961. New and redescribed species of Ledermuelleria from North America (Acarina: Stigmaeidae). Hilgardia, 31: 369-382.

Wainstein, B.A. and Kuznetsov, N.N. 1978. Family Stigmaeidae and Caligonellidae. In: M.S. Gilyarov (Ed.). Identification Key of Soil Inhabiting Mites. Trombidiformes. Nauka, Moscow, pp. 153-169. [In Russian]

Wood, T.G. 1972. New and redescribed species of Ledermuelleria Oudms, and Villersia Oudms (Acari: Stigmaeidae) from Canada. Acarologia, 13: 301-318.

Wood, T.G. 1973. Revision of Stigmaeidae (Acari: Prostigmata) in the Berlese Collection. Acarologia, 15: 67-69. 